
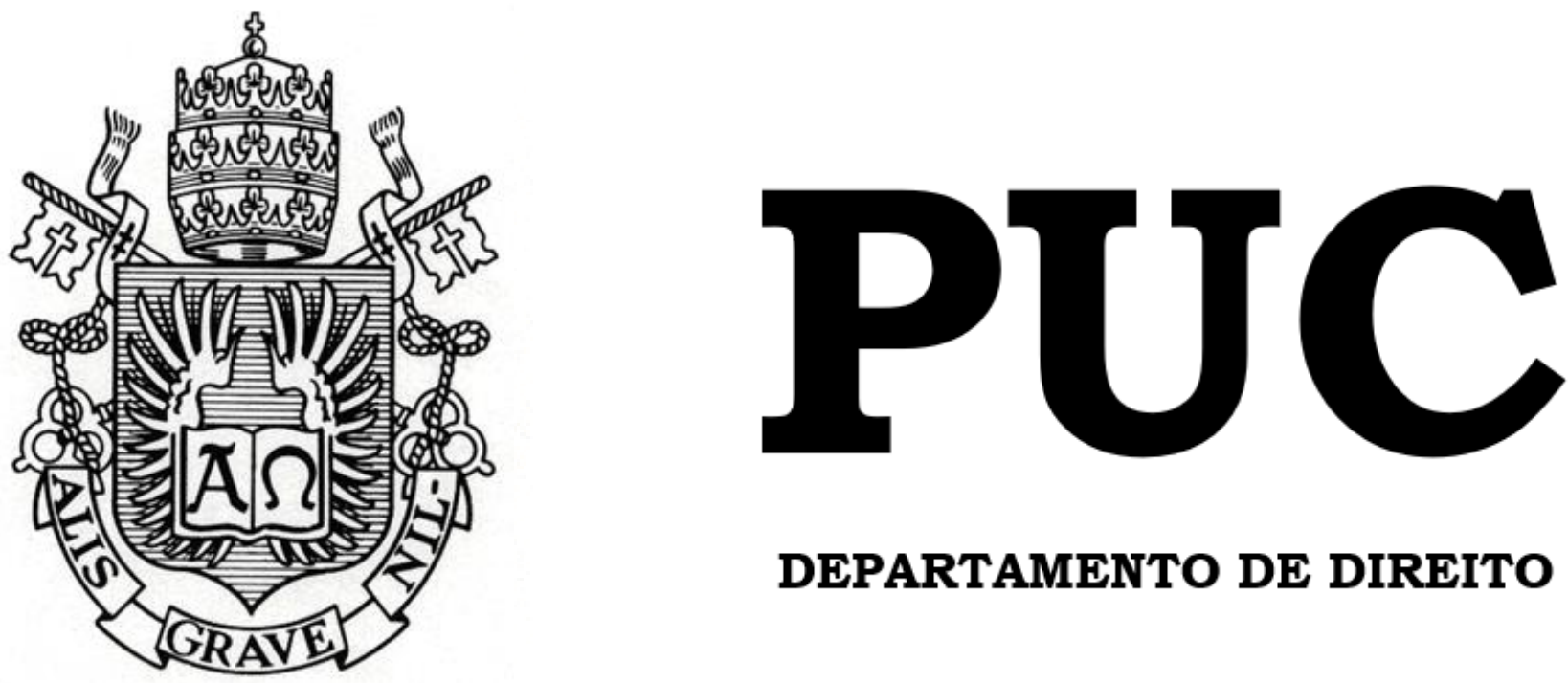

DEPARTAMENTO DE DIREITO

\title{
O QUITUS DOS ADMINISTRADORES DE SOCIEDADES ANÔNIMAS NO DIREITO BRASILEIRO
}

por

MARINA ANTUNES MACIEL SERTÃ

ORIENTADOR: PEDRO PAULO CRISTOFARO COORIENTADOR: JULIAN FONSECA PEÑA CHEDIAK

2018.2

PONTIFÍCIA UNIVERSIDADE CATÓLICA DO RIO DE JANEIRO

RUA MARQUÊS DE SÃO VICENTE, 225 - CEP 22453-900

RIO DE JANEIRO - BRASIL 


\section{O QUITUS DOS ADMINISTRADORES DE SOCIEDADES ANÔNIMAS NO DIREITO BRASILEIRO}

por

\section{MARINA ANTUNES MACIEL SERTÃ}

Monografia apresentada ao

Departamento de Direito da Pontifícia Universidade Católica do Rio de Janeiro (PUC-Rio) como requisito parcial para a obtenção do Título de Bacharel em Direito.

Orientador: Pedro Paulo Cristofaro

Coorientador: Julian Fonseca Peña Chediak 


\section{RESUMO}

O presente trabalho tem como objetivo promover uma análise das principais características da administração das sociedades anônimas e do sistema de responsabilidade dos administradores no direito brasileiro. Esta monografia estudará a exoneração de responsabilidade (quitus) outorgada pelos acionistas reunidos em assembleia ao aprovar as contas dos administradores e as demonstrações financeiras por eles elaboradas. Verificarse-á o tratamento que a nossa lei dá aos casos em que o quitus tenha sido outorgado, mas os acionistas desejam responsabilizar o administrador, sendo necessário primeiro ingressar com uma ação de desconstituição da quitação para então proceder com a ação de responsabilidade. Será feita uma análise dos problemas que a sistemática concebida pela nossa lei traz em relação a esta matéria, especialmente em relação à legitimidade processual e aos prazos prescricionais para essas ações. Por fim, serão feitas reflexões sobre como alguns desses conflitos poderiam ser resolvidos, usando como base para tanto o direito Português.

Palavras Chave: Direito Societário - Administradores - Sociedade Anônima

- Responsabilidade - Quitus - Exoneração - Direito Comparado - Direito Português - Desconstituição Judicial - Ação de Responsabilidade 


\section{SUMÁRIO}

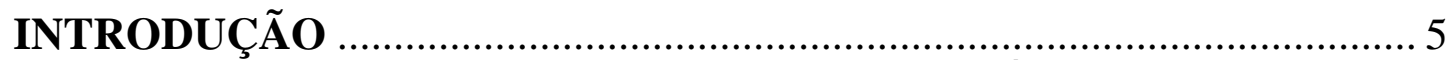

I - A ADMINISTRAÇÃO NAS SOCIEDADES ANÔNIMAS …............... 8

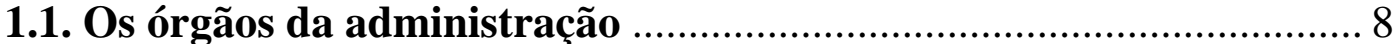

1.2. O administrador: relevância e atuação ............................................ 11

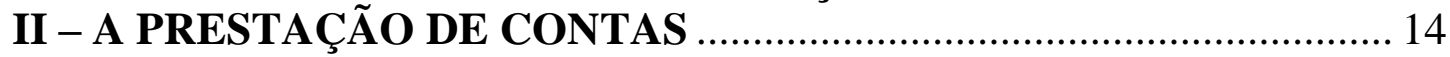

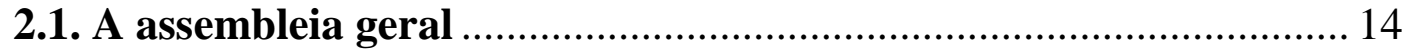

2.2. O relatório da administração e as demonstrações financeiras........ 17

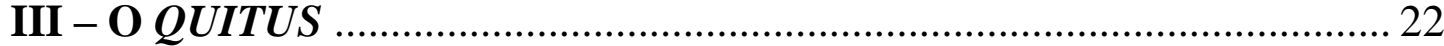

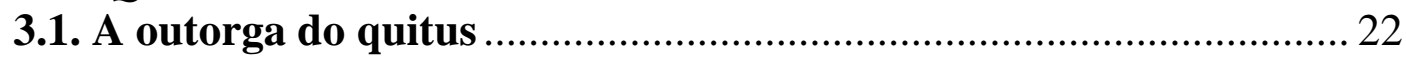

3.2. A extensão do quitus e a sua desconstituição …….......................... 25

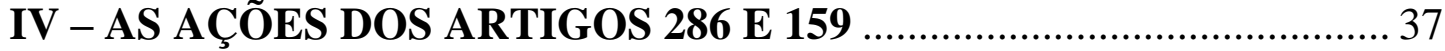

4.1. A ação para desconstituição do quitus (art. 286) …......................... 37

4.2. A ação de responsabilidade contra o administrador (art. 159) ....... 39

V - AS CONTRADIÇÕES DO SISTEMA BRASILEIRO …....................43

VI - REFLEXÕES PARA APRIMORAMENTO DO SISTEMA

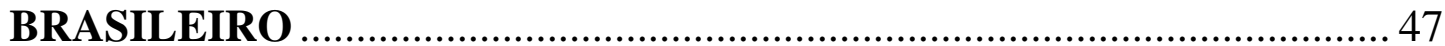

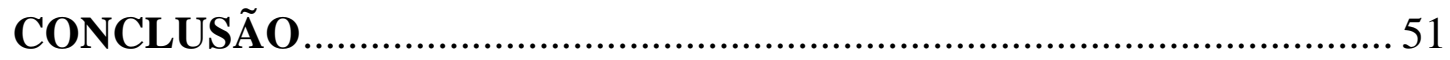

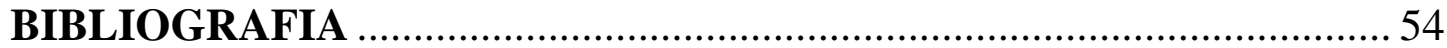




\section{INTRODUÇÃO}

As sociedades anônimas, reguladas pela Lei $\mathrm{n}^{\circ}$ 6.404/76 (Lei das Sociedades por Ações, ou "LSA") são um mecanismo que proporciona eficiência do uso do capital de terceiros para atingir um determinado fim - o objeto social - e gerar retorno sobre o capital inicialmente investido.

Esse mecanismo é composto de diversas partes que, trabalhando de forma coletiva e organizada, atingem um determinado nível de eficiência. Uma das principais partes desse coletivo, e que exerce papel fundamental em sua organização e funcionamento, é a administração.

O presente trabalho tratará justamente do conjunto de pessoas que compõem a administração social. Veremos que tais pessoas são, em última análise, responsáveis pela gestão do capital de terceiros, que reúnem seus recursos e os aportam em determinada sociedade, na crença de que o investimento gerará um bom retorno financeiro.

Se, por um lado, o trabalho desses indivíduos exige que tenham ampla liberdade de atuação, evitando o engessamento das atividades da administração, por outro, a separação entre propriedade e gestão demanda um sistema sofisticado de controle e fiscalização por meio da prestação de contas e da possibilidade de responsabilização, para coibir eventuais desvios de conduta.

O enfoque deste trabalho será um dos temas centrais desse sistema de responsabilidade: a quitação que os administradores recebem dos acionistas reunidos em assembleia, ao fim do exercício, conferida pela aprovação de suas contas e das demonstrações financeiras por eles preparadas.

Para tanto, faremos inicialmente um panorama geral da administração nas sociedades anônimas brasileiras, explicando a estrutura e funcionamento 
dos órgãos da administração, bem como a relevância e atuação do administrador em si.

Em seguida, passaremos à análise de como se dá a prestação de contas pelos administradores. Veremos o papel da assembleia geral, que, além de ser o órgão responsável por formar e exteriorizar a vontade da companhia, também é o ambiente onde os acionistas deliberam a aprovação das contas dos administradores e das demonstrações financeiras, exercendo o direito de fiscalização dessa atuação e outorgando, ou não, o quitus aos administradores. Trataremos também especificamente do relatório da administração e das demonstrações financeiras, que são os documentos elaborados e submetidos à análise e aprovação pelos acionistas.

Feito isso, chegaremos finalmente à análise do quitus em si, onde observaremos o que exatamente compreende a outorga do quitus, bem como a sua extensão. Trataremos da possibilidade de desconstituição do quitus, e dos diferentes entendimentos doutrinários sobre como fazê-lo.

Veremos que o quitus exonera os administradores de responsabilidade pelos atos abarcados pelo período da quitação, e impede a propositura pela companhia da ação de responsabilidade prevista no art. 159 da LSA. Assim, observaremos o caminho a ser percorrido nos casos em que a quitação tenha sido outorgada, mas se pretenda responsabilizar o administrador, estudando os detalhes da ação judicial para desconstituição da deliberação ou assembleia por meio da qual foi outorgada a quitação, e posteriormente da ação que busca a responsabilização do administrador.

Em seguida, desconstruiremos certos aspectos do sistema brasileiro sobre esse tema, entendendo porque a sistemática que a nossa lei criou para a exoneração de responsabilidade e para a desconstituição dessa exoneração que permite ressuscitar a via de responsabilidade apresenta certas contradições e incompatibilidades inerentes. 
Finalmente, o presente trabalho será concluído com breves reflexões sobre potenciais mudanças que permitiriam, se não uma resolução completa, ao menos uma mitigação dessas incongruências. 


\section{I - A ADMINISTRAÇÃO NAS SOCIEDADES ANÔNIMAS}

Inicialmente, para que se possa fazer uma análise adequada do instituto do quitus do administrador à luz do direito brasileiro, um panorama geral da administração nas sociedades anônimas se faz indispensável.

\subsection{Os órgãos da administração}

O funcionamento eficiente de uma companhia pressupõe a distribuição organizada das funções e deveres entre seus órgãos, para que formulem a vontade coletiva e para que possam exteriorizar essa vontade e executar o objeto da companhia. A crescente complexidade das sociedades, cada vez de maior porte, impõe um modelo de gestão especializado e compartimentalizado ${ }^{1}$.

A estruturação dos órgãos da administração das sociedades anônimas resulta de uma escolha do legislador. No vigente direito brasileiro, a administração pode ser conduzida pelo conselho de administração e pela diretoria, atuando em conjunto, ou somente pela diretoria ${ }^{2}$, conforme disposto no estatuto social. Esses órgãos são, em última análise, os responsáveis por garantir o regular funcionamento da companhia e a execução de sua vontade segundo o objeto social.

Enquanto que o conselho de administração exerce funções deliberativas e de organização interna, a diretoria é o órgão de representação legal da companhia, responsável pela execução das deliberações dos demais órgãos. O conselho recebe também a função de fiscalizar as atividades da diretoria.

\footnotetext{
${ }^{1}$ EIZIRIK, Nelson. A Lei das S/A Comentada. Vol. III, 2 ${ }^{\mathrm{a}}$ ed. São Paulo: Quartier Latin, 2015, p. 20.

${ }^{2}$ Art. 138 LSA.
} 
O conselho de administração constitui órgão de deliberação colegiada, cujos membros são obrigatoriamente eleitos pela assembleia geral ${ }^{3}$. A condição de acionista não é obrigatória para o exercício das funções de administração da companhia - tanto a de conselheiro quanto a de diretor.

O órgão é indispensável no caso de companhias abertas e companhias de capital autorizado, sendo facultativo para as demais.

Nelson Eizirik explica que "o conselho de administração é considerado o principal componente do sistema de governança corporativa, tendo como missão proteger e valorizar a organização, otimizar o retorno do investimento no longo prazo e buscar o equilíbrio entre as partes interessadas."

A competência do conselho de administração está expressa no art. 142 da LSA. Em síntese, compete ao órgão fixar a orientação geral dos negócios da companhia (art. 142, I), eleger e destituir os diretores e fixar suas atribuições (art. 142, II), fiscalizar a gestão dos diretores, examinar os documentos da companhia e solicitar informações relevantes para a gestão (art. 142, III), convocar a assembleia (art. 142, IV), manifestar-se sobre o relatório da administração e contas da diretoria, bem como sobre atos ou contratos, quando exigido pelo estatuto (art. 142, V e VI), deliberar a emissão de ações ou de bônus de subscrição (art. 142, VII), autorizar a alienação de bens do ativo não circulante, constituir ônus reais e prestar garantias a obrigações de terceiros, quando não proibido pelo estatuto (art. 142, VIII), e, por fim, escolher e destituir os auditores independentes, se houver (art. 142, IX).

Apesar de o conselho de administração guardar amplo espectro de atribuições, seus integrantes não têm poderes de representação da companhia, sendo essa competência exclusiva da diretoria. Evidencia-se assim a função

\footnotetext{
${ }^{3}$ Art. 140 LSA.

${ }^{4}$ EIZIRIK, Nelson. A Lei das S/A Comentada. Vol. III, 2a ed. São Paulo: Quartier Latin, 2015, p. 53.
} 
deliberativa do órgão, aspecto que possivelmente mais diferencia o cargo de conselheiro do cargo de diretor.

A diretoria exerce as funções executivas da sociedade, sendo os diretores os responsáveis pela orientação da sociedade em seus diversos aspectos, como a realização de negócios, a programação financeira, o comando de empregados e a implementação de novas técnicas ${ }^{5}$.

Diferentemente do conselho de administração, a diretoria é órgão obrigatório em toda e qualquer sociedade anônima.

$\mathrm{O}$ entendimento majoritário doutrinário explica que a relação entre o administrador e a companhia trata-se de contrato de administração sui generis $^{6 / 7}$. As características básicas desse contrato podem ser resumidas da seguinte forma: (i) é um contrato bilateral, estando de um lado o administrador e de outro a sociedade; (ii) as obrigações previstas no contrato são obrigações de meio e não de resultado; (iii) o administrador deve atuar em favor da companhia; e (iv) o administrador atua com autonomia dentro do escopo de suas atribuições.

No sistema brasileiro, os administradores são considerados órgãos da sociedade. A condição de administrador decorre não de um mandato da sociedade, mas do ato jurídico unilateral de sua nomeação, mediante o qual the são atribuídos poderes e deveres que o qualificam como órgão social. $\mathrm{Na}$ expressão de Pontes de Miranda, o administrador "presenta" a companhia, praticando atos que entram no mundo jurídico como atos da própria sociedade $^{8 / 9}$.

\footnotetext{
5 RAMALHETE, Vanessa Santos Neves. Responsabilidade dos Administradores de Sociedades Anônimas. Rio de Janeiro: Lumen Juris, 2009, p. 53.

${ }^{6}$ ADAMEK, Marcelo Vieira Von. Responsabilidade Civil dos Administradores de S/A (e as ações correlatas). São Paulo: Saraiva, 2009, p. 48.

${ }^{7} \mathrm{O}$ autor explica que este também é o entendimento que prevalece na Itália, e que vai se firmando como majoritário em Portugal.

${ }^{8}$ EIZIRIK, Nelson. A Lei das S/A Comentada. Vol. III, 2a ed. São Paulo: Quartier Latin, 2015, p. 171.

${ }^{9}$ PONTES DE MIRANDA. Tratado de Direito Privado. T. L, $3^{\text {a }}$ ed. São Paulo: Revista dos Tribunais, 1984, p. 385.
} 


\section{2. $O$ administrador: relevância e atuação}

Sabe-se que a sociedade anônima é um veículo de otimização de recursos como tempo e capital. O objetivo daqueles que aportam capital numa sociedade que persegue certo objeto é o de ver o desenvolvimento daquele empreendimento com os melhores resultados possíveis e um retorno para o seu investimento, sempre em conformidade com a lei e com aquele objeto social.

A administração é responsável por determinar e executar a vontade da sociedade dentro dos parâmetros do seu objeto social. A tomada de decisões, a avaliação de risco versus retorno e as propostas de mudanças e inovações ficam a cargo da administração, que precisa, portanto, de grande autonomia para sua atuação.

Assim, o administrador detém amplos poderes no âmbito da companhia, especialmente nos casos de companhias com capital pulverizado. Além disso, em razão do absenteísmo dos acionistas, muitas vezes o poder de fato é exercido pela administração da companhia e não pela assembleia geral.

Luiz Antonio de Sampaio Campos, na seção do Direito das Companhias que trata dos deveres e responsabilidades dos administradores, ressalta a relevância e sensibilidade do tema, notadamente em razão do fenômeno representado pela separação entre propriedade e gestão ${ }^{10}$.

Afinal de contas, os administradores têm o poder de determinar os rumos da sociedade, mas sequer precisam ser acionistas. Muitas vezes nem são seus próprios recursos, portanto, que estão submetidos aos riscos daquela gestão.

\footnotetext{
${ }^{10}$ CAMPOS, Luiz Antonio de Sampaio. Conselho de administração e diretoria. In: LAMY FILHO, Alfredo; PEDREIRA, José Luiz Bulhões (coord.). Direito das Companhias. Rio de Janeiro: Forense, 2009, p. 790.
} 
Por esse motivo, e conforme explicado na justificação do anteprojeto da LSA, o legislador estabelece como contrapartida ao poder e liberdade de atuação dos administradores diversos deveres e todo um sistema de responsabilidade e controle da atuação. A importância do tema foi muito ressaltada na Exposição de Motivos da LSA, ao comentar a Seção IV da lei, sobre os deveres e responsabilidades dos administradores:

"É a Seção de maior importância no Projeto porque procura fixar os padrões de comportamento dos administradores, cuja observância constitui a verdadeira defesa da minoria e torna efetiva a imprescindivel responsabilidade social do empresário. Não é mais possivel que a parcela do poder, em alguns casos gigantesca, de que fruem as empresas - e, através delas, seus controladores e administradores - seja exercido em proveito apenas dos sócios majoritários ou dirigentes, e não da companhia, que tem outros sócios, e em detrimento, ou sem levar em consideração, os interesses da comunidade." 11

Tais deveres e responsabilidades estão compreendidos nos arts. 153 a 160, e aplicam-se indistintamente aos membros dos órgãos da administração, sejam eles diretores ou conselheiros.

Esses dispositivos enumeram os principais deveres impostos aos administradores: (i) dever de diligência (art. 153); (ii) dever de cumprir com a finalidade da companhia/interesse social (art. 154); (iii) dever de lealdade (art. 155); (iv) dever de não agir em conflito de interesses (art. 156); e (v) dever de informar (art. 157).

Além desses deveres expressos, há também diversas obrigações assessórias contidas ao longo da lei (como a obrigação de disponibilizar documentos aos acionistas previamente à assembleia geral) ou que podem ser depreendidas como extensão de suas atribuições.

$\mathrm{O}$ art. 158 da LSA explica que o administrador não é pessoalmente responsável pelas obrigações que contrair em nome da sociedade e em virtude de ato regular de gestão. Nesses casos, é a própria companhia que responde - o 
administrador foi apenas o veículo por meio do qual a companhia praticou o ato e contraiu a obrigação.

Por outro lado, o administrador responderá civilmente por prejuízos causados quando atuar dentro de suas atribuições, com culpa ou dolo, ou com violação da lei ou do estatuto.

Para que o administrador tenha liberdade de atuação e espaço para tomada de riscos, ele só será pessoalmente responsável se for comprovado que ele tenha agido com culpa ou dolo, ou em violação da lei ou do estatuto. Assim, eventuais danos causados à companhia pelo insucesso do empreendimento não serão imputados ao administrador.

${ }^{11}$ Cf. Exposição de Motivos do Ministro da Fazenda no 196, de 24.06.76, DCN, Seção 1, Suplemento ao no 85, de 07.08.76, Cap. XII, Seção IV. 


\section{II - A PRESTAÇÃO DE CONTAS}

\subsection{A assembleia geral}

Vimos que os administradores são, em última análise, responsáveis pela gestão de recursos de terceiros. E é por isso que, ao fim do exercício social, eles têm a obrigação de prestar contas, elaborar e submeter as demonstrações financeiras à deliberação pelos acionistas.

Antes de passarmos a uma análise mais profunda do que trata a prestação de contas pelos administradores e quais são as implicações da aprovação ou rejeição de suas contas, é essencial fazer algumas considerações sobre a assembleia geral.

Além de ser o órgão máximo da companhia, formado pelo conjunto de acionistas convocados para deliberar os assuntos relativos ao interesse social e funcionamento da companhia, é na assembleia geral ordinária que a atuação dos administradores ao longo do exercício social é apreciada.

Ricardo Tepedino, na seção do Direito das Companhias que trata da assembleia geral, explica que "os acionistas exercem a função de integrantes da assembleia geral, e, quando nela congregados, contribuem, com suas manifestações e votos, para a formação da vontade social. ${ }^{12}$ "

Nesse sentido, a assembleia é o ambiente onde são expostas as diferentes vontades dos acionistas e, por meio do princípio majoritário, concretizada a vontade da companhia, sendo desconsiderados os votos que não prevaleceram nas matérias submetidas a deliberação.

Endemann ensina que, aprovada uma deliberação em assembleia, as diferenças entre maioria e minoria desaparecem, remanescendo apenas uma

12 TEPEDINO, Ricardo. Assembleia Geral. In: LAMY FILHO, Alfredo; PEDREIRA, José Luiz Bulhões (coord.). Direito das Companhias. Rio de Janeiro: Forense, 2009, v. I, p. 634. 
vontade única e indivisível, que constitui a decisão de última instância para todas as matérias que são de competência do órgão ${ }^{13}$.

É por isso que se diz que a deliberação da assembleia constitui ato unilateral da companhia, apesar de ser decorrente da manifestação de vontade dos acionistas ${ }^{14}$.

A assembleia geral ordinária deve obrigatoriamente ocorrer nos quatro primeiros meses seguintes ao término do exercício social, para deliberar certas matérias predeterminadas por lei. Já a assembleia geral extraordinária é convocada para que os acionistas possam apreciar os demais assuntos que surgirem ao longo do exercício social.

Trajano de Miranda Valverde explica que a deliberação a respeito das contas do exercício envolve duas apreciações distintas por parte da assembleia geral $^{15}$. São aquelas dispostas atualmente no art. 122, III, que determina caber privativamente à assembleia geral (i) "tomar, anualmente, as contas dos administradores"; e (ii) "deliberar sobre as demonstrações financeiras por eles apresentadas".

Como a competência da assembleia é privativa para a deliberação dessas matérias, isso torna o órgão de especial importância no estudo do quitus do administrador. $\mathrm{O}$ art. 132, I esclarece que os dois itens referidos acima serão obrigatoriamente submetidos à apreciação pela assembleia geral ordinária ${ }^{16}$.

Um dos direitos essenciais dos acionistas, cujo rol está previsto no art. 109 da LSA, é o direito de fiscalizar a gestão dos negócios sociais ${ }^{17}$. Esse é um dos dispositivos que serve como um contrapeso aos poderes dos

\footnotetext{
13 ENDEMANN, WILHEIM. Apud.: LAMY FILHO, Alfredo; PEDREIRA, José Luiz Bulhões (coord.). Direito das Companhias. Rio de Janeiro: Forense, 2009, p. 636.

${ }^{14}$ EIZIRIK, Nelson. A Lei das S/A Comentada. Vol. II, $2^{\mathrm{a}}$ ed. São Paulo: Quartier Latin, 2015, p. 301.

${ }^{15}$ VALVERDE, Trajano de Miranda. Sociedades por Ações, vol. II, $2^{\mathrm{a}}$ ed. Rio de Janeiro: Forense, 1953, p. 138.

${ }^{16}$ Art. 132. Anualmente, nos 4 (quatro) primeiros meses seguintes ao término do exercício social, deverá haver 1 (uma) assembleia-geral para:

I - tomar as contas dos administradores, examinar, discutir e votar as demonstrações financeiras.

${ }^{17}$ Art. 109, III, LSA.
} 
administradores. A fiscalização visa a prevenção do abuso do poder de gestão, e de eventuais excessos que tendem a ser mais facilmente praticados quando não há quem esteja vigiando.

No entanto, apesar de os acionistas serem titulares do direito de fiscalização, eles não têm ampla liberdade para determinar o meio pelo qual exercerão esse direito. O art. 109, III da LSA explica que o direito é o de "fiscalizar, na forma prevista nesta Lei, a gestão dos negócios sociais" (grifos nossos). Assim, cabe aos acionistas optar por alguma das opções predefinidas pelo legislador.

Isso porque, como as companhias são sociedades com capacidade de congregação de um grande número de sócios, a possibilidade de fiscalização ilimitada da gestão pelos acionistas poderia levar ao congelamento da atuação da administração e, consequentemente, à impossibilidade da consecução do objeto social e da obtenção de lucros ${ }^{18}$.

Nesse sentido, o direito de fiscalização tem forte ligação com a assembleia geral, na medida em que ela serve como um dos principais mecanismos para viabilização do exercício desse direito pelos acionistas. Como será visto adiante, a lei determina que os administradores têm a obrigação de apresentar certos documentos para análise e deliberação dos acionistas e prestar contas sobre a sua atuação naquele exercício social.

$\mathrm{O}$ fato de os administradores terem que prestar contas anualmente, as quais se sujeitam à aprovação pelos acionistas, permite a fiscalização da atuação dos administradores e é um estímulo para que eles atuem dentro dos conforme da lei, e em benefício da companhia, sob pena da rejeição de suas contas, da possibilidade de ingresso de ação de responsabilidade e consequente destituição. 


\subsection{O relatório da administração e as demonstrações financeiras}

$\mathrm{O}$ art. 133 da LSA determina que os administradores deverão disponibilizar, até um mês antes da data marcada para realização da assembleia geral ordinária, os seguintes documentos para apreciação dos acionistas: (i) o relatório da administração sobre os negócios sociais e os principais fatos administrativos do exercício findo; (ii) a cópia das demonstrações financeiras; (iii) o parecer dos auditores independentes, se houver; (iv) o parecer do conselho fiscal, inclusive votos dissidentes, se houver; e (v) demais documentos pertinentes a assuntos incluídos na ordem do dia.

Ou seja, os administradores terão o dever de, anualmente, elaborar o relatório da administração sobre os negócios sociais e os principais fatos administrativos do exercício findo, bem como as demonstrações financeiras. E a lei atribui à assembleia geral competência exclusiva para examinar esses documentos e tomar as contas dos administradores.

Nelson Eizirik explica que "o relatório de administração esclarece os principais fatos administrativos ocorridos no exercício findo, devendo expor com clareza todos os acontecimentos relacionados com a exploração do objeto social, as causas determinantes dos eventuais prejuízos, bem como as modificações ou alterações havidas na legislação que interessem a sociedade." 19

O relatório deve ainda explicar detalhadamente os itens contidos nas demonstrações financeiras e a proposta para distribuição de dividendos.

Trajano de Miranda Valverde sintetiza:

"O relatório deve apresentar com clareza todos os acontecimentos que influíram na exploração do objeto social, as causas determinantes dos prejuízos, as modificações

\footnotetext{
${ }^{18}$ EIZIRIK, Nelson. A Lei das S/A Comentada. Vol. II, $2^{\mathrm{a}}$ ed. São Paulo: Quartier Latin, 2011, p. 131132.

${ }^{19}$ EIZIRIK, Nelson. A Lei das S/A Comentada. Vol. II, 2a ed. São Paulo: Quartier Latin, 2015, p. 458.
} 
e alterações havidas na legislação, que interessar à sociedade, notadamente no que respeita a impostos e taxas. Explicará, quanto possivel, sem revelar segredos de indústria ou comércio, as verbas constantes do balanço, as importâncias levadas aos diferentes fundos de amortização e de reserva e finalizará com a proposta de distribuição de dividendo, na forma prescrita nos estatutos. Se a sociedade estiver filiada a outras ou sobre outras exercer o controle, a diretoria deverá também, no seu relatório, dar precisas informações sobre a situação dessas sociedades."

Já as demonstrações financeiras servem como uma espécie de retrato da situação patrimonial da sociedade ao final daquele exercício. José Luiz Bulhões Pedreira e Luiz Alberto Colonna Rosman esclarecem que elas não são elaboradas com a finalidade de prestar contas e sim de informar a situação patrimonial e os resultados da companhia. No entanto, elas acabam servindo de instrumento de prestação de contas porque os efeitos patrimoniais dos atos praticados pelos administradores são registrados na escrituração mercantil, a partir da qual são elaboradas as demonstrações ${ }^{21}$.

Assim, apesar de as demonstrações apresentarem saldos de contas (ou grupos de contas) da escrituração mercantil, e não atos singulares praticados pelos administradores, a sua leitura permite uma avaliação global do resultado da administração e sugere questões sobre os atos por ela praticados.

$\mathrm{O}$ art. 176 da LSA exige que a diretoria elabore, para esse fim, as seguintes demonstrações: (i) balanço patrimonial; (ii) demonstração dos lucros ou prejuízos acumulados; (iii) demonstração do resultado do exercício; (iv) demonstração dos fluxos de caixa; e, nos casos de companhias abertas, (v) demonstração do valor adicionado.

A assembleia examina e discute as demonstrações financeiras sob duas óticas distintas: na primeira, como instrumento de conhecimento das finanças

\footnotetext{
${ }^{20}$ VALVERDE, Trajano de Miranda. Sociedades por Ações. Vol. II, $2^{\mathrm{a}}$ ed. Rio de Janeiro: Forense, 1953, p. 130.

${ }^{21}$ PEDREIRA, José Luiz Bulhões; ROSMAN, Luiz Alberto Colonna, Aprovação das Demonstrações Financeiras, Tomada de Contas dos Administradores e seus Efeitos. Necessidade de Prévia Anulação da Deliberação que Aprovou as Contas dos Administradores para a Propositura de Ação de Responsabilidade. In: CASTRO, Rodrigo R. Monteiro de; ARAGÃO, Leandro Santos de. Sociedade Anônima - 30 Anos da Lei 6.404/76. São Paulo: Quartier Latin, 2007, p. 43.
} 
da companhia e, na segunda, como instrumento de tomada de contas, com o fim de julgar os atos dos administradores e, se for o caso, promover ação de responsabilidade contra eles.

Até serem aprovadas pela assembleia as demonstrações financeiras são um mero projeto sobre o estado contábil da companhia. Depois de aprovadas, elas ganham condição jurídica de ato declaratório e se tornam uma declaração oficial, capaz por si só de demonstrar naquele momento dados sobre a sociedade como o patrimônio líquido, o lucro disponível e o resultado das operações.

Conforme mencionado acima, a lei procura dar efetividade ao direito dos acionistas de fiscalizar a atuação dos administradores ao (i) obrigar os administradores a preparar e apresentar um rol de documentos que em tese permita aos acionistas ter uma visão adequada sobre a gestão e o resultado daquele exercício; e (ii) permitir que os acionistas deliberem sobre aqueles documentos, podendo inclusive propor ajustes ou rejeita-los completamente.

No entanto, será que as medidas propostas pela lei permitem uma forma efetiva de exercício desse direito? Será que os documentos previstos no art. 133 da LSA (que os acionistas têm um mês para apreciar antes da assembleia), permitem uma adequada apreciação da gestão e da situação patrimonial da companhia?

Sobre o assunto, já em 1958, Waldemar Ferreira propunha a seguinte reflexão:

"O balanço, de resto, é peça contabilística de sumariedade tal que não pode compreender todos os atos praticados pelos diretores. Elaborado de acordo com as prescrições legais, pode estar aparentemente correto, mas fundamentalmente errado mercê de administração desastrada, senão mesmo dolosa. Nele se oferecem apenas somas totais de verbas restritas, sem nenhuma referência aos diversos atos e contratos celebrados em prejuízo da sociedade e até em benefício dos próprios diretores." 22

\footnotetext{
${ }^{22}$ FERREIRA, Waldemar. Tratado das Sociedades Mercantis. Rio de Janeiro: Editora Nacional, 1958, p. 1817.
} 
$\mathrm{Na}$ doutrina contemporânea, esse tema permanece alvo de questionamentos. José Edwaldo Tavares Borba, por exemplo, afirma que " $a$ aprovação das contas dos administradores é de natureza formal, posto que a assembleia não tem a oportunidade de se aprofundar no exame das operações realizadas durante o exercício" 23.

Assim, apesar de a legislação atual ter ampliado o espectro de informações que compõem as demonstrações financeiras, elas não oferecem senão agrupamentos de contas, de modo a proporcionar aos que analisam esses documentos um quadro ilustrativo da situação da empresa. Borba conclui:

"As demonstrações financeiras sofrem o influxo, e até mesmo resultam, dos negócios e contratos que a empresa empreendeu e realizou, mas as operações celebradas e as suas implicações específicas não se revelam, de forma plena, nas demonstrações financeiras. A assembleia delas não toma conhecimento, e nem mesmo poderia fazêlo, considerada a multiplicidade e a extensão desses atos. ${ }^{24}$

A dificuldade de análise adequada das contas e demonstrações financeiras pelos acionistas guarda relação não apenas com o teor dos documentos, mas também com o prazo para análise.

Por um lado, é razoável que o prazo para análise de documentos a serem discutidos em assembleia não seja extenso demais, até porque se forem elaborados pela administração com demasiada antecedência, podem já estar desatualizados no momento de análise.

Por outro lado, 30 dias geralmente não serão suficientes para um estudo e avaliação crítica de dados contábeis, extratos de resultados e relatórios extensos - especialmente considerando que acionistas normalmente não têm conhecimento técnico que lhes permita esse tipo de análise.

\footnotetext{
${ }^{23}$ BORBA, José Edwaldo Tavares. In: FILHO, Alberto Venancio; LOBO, Carlos Augusto da Silveira; ROSMAN, Luiz Alberto Colonna (org.). Lei das S.A. em seus 40 anos, $1^{\text {a }}$ ed. Rio de Janeiro: Forense, 2017, p. 522-523.

${ }^{24}$ Ibid. p. 522-523.
} 
Assim, apesar da pretensão da lei acionária de dar efetividade ao direito dos acionistas de fiscalizar a atuação dos administradores, discute-se a eficácia da medida em razão (i) do teor dos documentos fornecidos para esse fim e (ii) do prazo para análise desses documentos. 


\section{III - O QUITUS}

\subsection{A outorga do quitus}

Não obstante a discussão sobre se os documentos previstos no art. 133 permitem aos acionistas uma adequada compreensão dos resultados da companhia e da atuação dos administradores, o fato é que eles receberão os documentos, terão pelo menos um mês para analisa-los, e então terão que deliberar sobre a aprovação (ou não) das contas e das demonstrações financeiras ${ }^{25}$.

Caso os acionistas vislumbrem alguma ilegalidade, dolo ou negligência na atuação dos administradores, eles poderão rejeitar as contas, e inclusive propor a ação de responsabilidade contra o administrador por prejuízos ao patrimônio da companhia, prevista no art. 159 da LSA.

Vale lembrar que, caso os acionistas resolvam não aprovar as contas, é importante que o façam de forma motivada. A deliberação que rejeitar as contas precisa ser bem fundamentada, enumerando os motivos para tanto e os atos supostamente irregulares praticados. Votar pela rejeição das contas de forma infundada caracteriza abuso do acionista no exercício do direito de voto.

Por outro lado, caso os acionistas entendam que as contas dos administradores refletem uma atuação adequada, em conformidade com a lei e com o objeto social, e nos melhores interesses da sociedade, devem eles aprovar, as contas dos administradores e as demonstrações financeiras por eles preparadas.

\footnotetext{
25 Já foi mencionado que os administradores não precisam obrigatoriamente ser acionistas da companhia. No entanto, quando eles ocuparem a posição de acionistas ou de seus procuradores em assembleia, a lei proíbe expressamente que os gestores votem na deliberação sobre suas próprias contas (art. $115, \S 1^{\circ}$, e art. $134, \S 1^{\circ}$ ). Trata-se de uma vedação à atuação dos administradores em conflito de interesses, como juízes em causa própria.
} 
$\mathrm{O}$ art. $134, \S^{\circ}$ da $\mathrm{LSA}^{26}$ determina que a aprovação, sem reservas, das demonstrações financeiras e das contas dos administradores os exonera de responsabilidade em relação àquele período específico. É justamente essa quitação, essa exoneração, que constitui o quitus, objeto principal do presente trabalho.

O quitus é a outorga pelos acionistas da quitação das obrigações legal e estatutariamente assumidas pelos administradores. Essa exoneração pressupõe que os acionistas, reunidos em assembleia e após terem tido oportunidade de avaliar os documentos pertinentes, estão de acordo com a atuação e gestão dos administradores durante o período compreendido.

O quitus serve como uma salvaguarda ao arriscado trabalho dos administradores. Alfredo Sérgio Lazzareschi Neto bem explica essa função:

"Ao assumirem a delicada missão de administrar os negócios sociais, os administradores colocam em risco seu nome e patrimônio em prol da companhia. Justamente por isso a Lei Societária lhes confere certas salvaguardas, sem as quais profissionais capacitados, respeitados e responsáveis jamais aceitariam exercer tal função. Daí o legislador ter criado dois 'portos-seguros' em favor dos administradores: (i) a regra da decisão negocial (business judgment rule, originada no Direito norte-americano, e, de certa forma, refletida no art. $159, \S 6^{\circ}$, da Lei das S.A.), segundo a qual os gestores não são pessoalmente responsáveis por prejuízos causados por erros de avaliação cometidos de boa-fé na condução dos negócios sociais; e (ii) a exoneração de responsabilidade dos administradores mediante a aprovação, sem reservas, das contas e das demonstrações financeiras. ${ }^{27}$

Percebe-se que o quitus confere aos administradores segurança jurídica para desempenharem suas atividades. Entendemos que o legislador fez bem ao prever essa quitação aos administradores cujas contas foram aprovadas. Se

\footnotetext{
${ }^{26}$ Art. 134. Instalada a assembléia-geral, proceder-se-á, se requerida por qualquer acionista, à leitura dos documentos referidos no artigo 133 e do parecer do conselho fiscal, se houver, os quais serão submetidos pela mesa à discussão e votação.

(...)

$\S 3^{\circ}$ A aprovação, sem reserva, das demonstrações financeiras e das contas, exonera de responsabilidade os administradores e fiscais, salvo erro, dolo, fraude ou simulação (artigo 286).

${ }^{27}$ LAZZARESCHI NETO, Alfredo Sérgio. Efeitos da Aprovação das Contas e das Demonstrações Financeiras das Companhias. In: KUYVEN, Luiz Fernando Martins. Temas essenciais de direito empresarial: estudos em homenagem a Modesto Carvalhosa. São Paulo: Saraiva, 2012, p. 423-424.
} 
assim não fosse, pessoas capacitadas e sérias ficariam desincentivadas a assumir o cargo de administrador de sociedades, pois estariam expostas e sujeitas, por tempo indeterminado, a testes e ataques potencialmente injustos.

Voltando à outorga do quitus, ressalta-se que a aprovação das contas não necessariamente ocorre de forma conjunta para todos os administradores, sendo possível aprovar as contas de um e não aprovar as dos outros, e viceversa.

Além disso, a aprovação das demonstrações financeiras não implica necessariamente a aprovação das contas dos administradores. Isso porque pode haver situação em que os administradores tenham realizado operações danosas, cometendo atos dolosos ou culposos e em prejuízo à sociedade, mas as demonstrações tenham sido corretamente elaboradas e expressem adequadamente a situação financeira da sociedade, inclusive os prejuízos decorrentes da má atuação da administração.

Nesses casos, os acionistas podem e devem aprovar o balanço, já que este representa retrato fidedigno da situação patrimonial da sociedade, mas estabelecerão reservas em relação a certos atos dos administradores, ou rejeitarão por completo as suas contas.

Não há incompatibilidade entre a reserva ou rejeição das contas e a aprovação do balanço quando o prejuízo de eventual ato danoso praticado pela administração estiver devidamente refletido no balanço (que estará, portanto, correto).

A propósito, e ainda na vigência da lei de 1940, Trajano de Miranda Valverde explicava que "o balanço pode refletir a situação real da sociedade e ter sido apresentado, pela diretoria, com estrita observância das prescrições legais. Mas a gestão dos negócios sociais pode ter sido desastrosa, em consequência de atos ou operações praticadas pelos diretores, com manifesta imprudência, imperícia ou negligência. Podem eles ter violado a lei ou o estatuto e até agido maliciosamente na administração da sociedade. 
Verificada a exatidão do balanço, a assembleia não deixará de aprova-lo, sem que, entretanto, essa aprovação envolva a aprovação dos resultados que ele positiva. A aprovação do balanço não significa, pois, a exoneração da responsabilidade dos diretores e fiscais. ${ }^{28,}$

Nas palavras de Alfredo Sérgio Lazzareschi Neto, "a função da reserva é possibilitar a aprovação das demonstrações financeiras sem a exoneração da responsabilidade dos administradores. ${ }^{29}$

Por tratar-se de uma ressalva ou protesto, a doutrina ${ }^{30 / 31 / 32}$ ressalta que a reserva há de ser expressa, aprovada pela maioria e consignada na ata da própria assembleia geral ordinária. O Superior Tribunal de Justiça já manifestou o mesmo entendimento ${ }^{33}$.

$\mathrm{Na}$ mesma lógica, a assembleia pode introduzir modificações na proposta das demonstrações financeiras mas aprovar as contas dos administradores, se as razões de modificação nas demonstrações financeiras não resultarem da descoberta de atos ilícitos dos administradores ${ }^{34}$.

\subsection{A extensão do quitus e a sua desconstituição}

\footnotetext{
${ }^{28}$ VALVERDE, Trajano de Miranda. Sociedades por Ações. vol. II, $2^{\mathrm{a}}$ ed. Rio de Janeiro: Forense, p. 138.

${ }^{29}$ Ibid. p. 418.

${ }^{30}$ Ibid. p. 419.

${ }^{31}$ CAMPOS. Luiz Antonio de Sampaio. Conselho de administração e diretoria. In: LAMY FILHO, Alfredo; PEDREIRA, José Luiz Bulhões (coord.). Direito das Companhias. Rio de Janeiro: Forense, 2009, p. 1252.

${ }^{32}$ GUIMARAES, Ruy Carneiro. Sociedades por ações. Rio de Janeiro: Forense, 1960, p. 274.

${ }^{33}$ STJ, AgRg no Ag 950104/DF, Rel. Min. Massami Yueda, DJe 30.03.2009: "Enfatize-se que a ressalva na aprovacao das contas a que alude o art. 134, $\$ 3^{\circ}$, da Lei $n .6 .404 / 76$ é feita pela assembleia geral, e nao pelos votos minoritários (...)"

${ }^{34}$ PEDREIRA, José Luiz Bulhões; ROSMAN, Luiz Alberto Colonna. Aprovação das Demonstrações Financeiras, Tomada de Contas dos Administradores e seus Efeitos. Necessidade de Prévia Anulação da Deliberação que Aprovou as Contas dos Administradores para a Propositura de Ação de Responsabilidade. In: CASTRO, Rodrigo R. Monteiro de; ARAGÃO, Leandro Santos de. Sociedade Anônima - 30 Anos da Lei 6.404/76. São Paulo: Quartier Latin, 2007, p. 48.
} 
Diferentemente das hipóteses de rejeição das contas ou de aprovação com reservas, quando os acionistas aprovarem as contas e as demonstrações financeiras sem reservas, os administradores receberão a mencionada exoneração das responsabilidades compreendidas no período abarcado pela quitação.

Por meio do quitus, os acionistas assinam sua concordância com o modo de gestão da companhia por parte dos administradores. Neste sentido, Fran Martins explica:

"A aprovação sem reservas pressupõe que os acionistas concordam com a atuação dos administradores e com as opiniões dos fiscais a respeito das contas $e$ demonstrações financeiras apresentadas à assembleia." 35

A partir da deliberação que outorga o quitus, os administradores ficam liberados de responsabilidade por eventuais prejuízos causados à companhia, e a assembleia geral fica, em princípio, impedida de aprovar a propositura de ação de responsabilidade de que trata o art. 159 da $\operatorname{LSA}^{36}$.

Mas até onde vai a quitação de responsabilidade outorgada pelos acionistas? Ela é realmente plena?

Inicialmente, vale fazer breve parêntese sobre o alcance subjetivo do quitus para lembrar que, apesar de a aprovação sem reserva implicar na exoneração de responsabilidade dos administradores em relação aos prejuízos causados à companhia, o mesmo não ocorre em relação aos danos causados pelos administradores diretamente aos acionistas. A doutrina explica que esses danos podem ser objeto de ação individual prevista no art. $159, \S 7^{\circ}$ da LSA:

\footnotetext{
${ }^{35}$ MARTINS, Fran. Comentários à Lei das Sociedades Anônimas, t. 1, vol. 2. Rio de Janeiro: Forense, 2010, p. 234.

36 Art. 159. Compete à companhia, mediante prévia deliberação da assembléia-geral, a ação de responsabilidade civil contra o administrador, pelos prejuízos causados ao seu patrimônio.
} 
"É que, como nessa hipótese os danos foram causados diretamente aos acionistas, somente estes, e não a companhia, podem dar o "quitus", já que são eles, e não a companhia, os titulares de pretensão contra os administradores. A assembleia geral não tem poder de exonerar os administradores no tocante a direitos que não pertencem à companhia, mas aos acionistas individualmente.

Disso decorre que a aprovação sem reserva, ainda que deliberada em assembleia pelos próprios acionistas diretamente prejudicados pelos administradores, em nada afeta a ação individual. Quando reunidos em assembleia, os acionistas deliberam sobre direitos e interesses da companhia, e não sobre eventuais pretensões individuais contra os administradores." ${ }^{37}$

Fechando o aparte e retomando o enfoque do presente trabalho, diz-se que o quitus confere uma espécie de blindagem ao administrador contra a instauração de ação de responsabilidade prevista no caput do art. 159 da LSA. A lei, no entanto, prevê uma exceção a essa blindagem: o quitus poderá ser anulado por decisão judicial ou arbitral $^{38}$, por meio da ação prevista no art. 286 da $\operatorname{LSA}^{39}$.

A ação caberá quando a assembleia como um todo tenha sido irregularmente convocada ou instalada, ou quando ela ou a deliberação por meio da qual o quitus tiver sido concedido sejam violadoras da lei ou do estatuto, ou eivadas de erro, dolo, fraude ou simulação. O prazo prescricional para a ação é de 2 anos, contados da deliberação.

Fran Martins explica:

"Mas a aprovação não isenta os administradores e fiscais no caso de ser provado que agiram eles com erro, dolo, fraude ou simulação. Esses são fatos que necessitam ser provados e a ação anulatória da deliberação que aprovou as contas dos administradores e as demonstrações financeiras tem o prazo prescricional de dois anos, contados da data da deliberação (art. 286). Esses vícios também podem ter

${ }^{37}$ LAZZARESCHI NETO, Alfredo Sérgio. Efeitos da Aprovação das Contas e das Demonstrações Financeiras das Companhias. In: KUYVEN, Luiz Fernando Martins. Temas essenciais de direito empresarial: estudos em homenagem a Modesto Carvalhosa. São Paulo: Saraiva, 2012, p. 425.

38 A propósito, vale lembrar que o art. 109, $\S 3^{\circ}$ da LSA determina que "o estatuto da sociedade pode estabelecer que as divergências entre os acionistas e a companhia, ou entre os acionistas controladores e os acionistas minoritários, poderão ser solucionadas mediante arbitragem, nos termos em que especificar." Assim, a matéria poderá ser sujeita à resolução por um tribunal arbitral.

39 Art. 286. A ação para anular as deliberações tomadas em assembléia-geral ou especial, irregularmente convocada ou instalada, violadoras da lei ou do estatuto, ou eivadas de erro, dolo, fraude ou simulação, prescreve em 2 (dois) anos, contados da deliberação. 
sido praticados pela assembleia com a finalidade de favorecer os administradores. Procura-se, por isso, anular a decisão que aprovou as contas, para que seja apurada a responsabilidade dos administradores nos termos dos art. 158 e 159."40

Em relação à assembleia em si, a disciplina geral da convocação e instalação das assembleias está expressa nos arts. 123 a 128 da LSA. A violação dessas disposições, portanto, ou de normas estatutárias que as complementem, acarreta a anulabilidade da assembleia e, consequentemente, de todas as suas deliberações ${ }^{41}$.

Destaca-se que a ocorrência de defeitos na convocação ou instalação não esgota os casos de irregularidades que se podem classificar como vícios $d a$ assembleia. Dentre esses casos encontram-se também, por exemplo: (i) inobservância da ordem do dia; (ii) recusa de participação ao acionista ou seu representante; (iii) inexistência de quórum legal ou estatutário das deliberações; (iv) falta de lavratura da ata; (v) ausência de publicação prévia dos documentos da administração; e (vi) inobservância do procedimento e demais formalidades estabelecidas em lei ${ }^{42}$.

Em relação aos vícios das deliberações, essas também podem ser nulas ou anuláveis quando forem violadoras da lei ou do estatuto. É o caso, por exemplo, de deliberação que determina que certa classe de ações terá direito a voto plural. A deliberação pode ter ocorrido no âmbito de uma assembleia corretamente convocada e instalada, mas como o teor da deliberação é manifestamente contrário à lei, a deliberação poderá ser objeto da ação de anulação.

Com relação às hipóteses de erro, dolo, fraude ou simulação, tratam-se de defeitos ou causas de invalidade dos atos jurídicos em geral. São vícios de

\footnotetext{
${ }^{40}$ MARTINS, Fran. Comentários à Lei das Sociedades Anônimas, t. 1, vol. 2. Rio de Janeiro: Forense, 2010, p. 486.

${ }^{41}$ NOVAES FRANÇA, Erasmo Valladão Azevedo. Invalidade das deliberações de assembleia das S.A. São Paulo: Malheiros, 1999, p. 88.

${ }^{42}$ Ibid. p. 91-97.
} 
vontade que contaminam um ato jurídico que, se não fosse por isso, seria perfeito.

Marcelo Vieira Von Adamek explica que erro (CC, arts. 138 a 144), dolo (arts. 145 a 150) e coação (CC, arts. 151 a 155) são vícios do consentimento, e fraude contra credores (CC, arts. 158 a 165), fraude à lei imperativa (CC, art. 166, VI) e simulação (CC, art. 167) são vícios sociais. Exceção feita à simulação e à fraude à lei, que importam na nulidade absoluta do negócio jurídico (a não ser na hipótese excepcional do art. 48, pár. ún. do $\mathrm{CC}$ ), os demais implicam sua nulidade relativa, ou anulabilidade ${ }^{43}$.

Um exemplo é a hipótese do acionista que profere voto por erro acerca da situação econômico-financeira da sociedade, expressa em balanço irregular, ou em virtude de dolo dos administradores que criaram e mantiveram aquela irregularidade propositalmente.

Uma hipótese de simulação, por sua vez, se dá quando um administrador burla a proibição de votar em suas próprias contas, transferindo suas ações a outra pessoa que delibere nesse sentido por ele. Já a fraude pode ocorrer por meio de uma deliberação que autorize a venda ou oneração fraudulenta de um bem.

Assim, quando os administradores tiverem sido exonerados de suas responsabilidades, mas os acionistas verificarem que a assembleia ou deliberação que aprovou as contas continha algum desses vícios de vontade, eles deverão buscar a desconstituição do quitus para então ingressarem com a ação de responsabilidade prevista no art. 159 da LSA.

Existe uma discussão doutrinária da qual resultam duas visões sobre a forma correta para efetivar a desconstituição do quitus.

43 ADAMEK, Marcelo Vieira Von. Responsabilidade dos Administradores de S/A e as ações correlatas. São Paulo: Saraiva, 2009, p. 253-254. 
Parte da doutrina entende que a própria assembleia geral é capaz de anular ou revogar a deliberação prévia por meio da qual foram aprovadas as contas e outorgada a quitação. Essa parcela da doutrina é minoritária, mas carrega nomes de peso, como de Modesto Carvalhosa e Marcelo Vieira Von Adamek.

Carvalhosa afirma, por exemplo, que "sendo o principal atributo da assembleia-geral ou da especial a sua soberania, cabe-lhes, em tempo oportuno, revogar as deliberações eivadas de irregularidades ou vícios" 44 .

Adamek reforça, explicando que " $a$ assembleia geral pode e deve rever as suas próprias deliberações, notadamente as inválidas, inclusive as de aprovação das contas e demonstrações financeiras" e concluindo que "cabe, assim, a retificação da deliberação de aprovação das contas (gestão) elou das demonstrações financeiras, com o consequente afastamento do efeito extintivo do quitus" ${ }^{\prime 4}$.

Carvalhosa vai além ao afirmar que a revogação do quitus nem precisaria ser deliberada pela assembleia, pois decorreria automaticamente da aprovação da propositura da ação de responsabilidade prevista no art. 159 da LSA. O jurista explica:

"Deliberando a assembleia geral acionar os administradores, estará obviamente retificando sua deliberação anterior da aprovação das contas daqueles, já que o pressuposto é o da existência de fraude. Portanto, a deliberação de agir contra os administradores, para responsabilizá-los, automaticamente anula a deliberação anterior de aprovação de ressalvas ",46.

Outro entendimento interessante é o de José Edwaldo Tavares Borba, que entende que o quitus configura uma mera presunção de que a gestão foi

\footnotetext{
${ }^{44}$ CARVALHOSA, Modesto. Comentários à Lei de Sociedades Anônimas. Vol. IV, $5^{\text {a }}$ ed. São Paulo: Saraiva, 2014, p. 554-555.

${ }^{45}$ ADAMEK, Marcelo Vieira Von. Op. Cit., p. 277 e 279.

${ }^{46}$ CARVALHOSA, Modesto. Op. Cit., p. 391.
} 
regular, mas que apenas prevalece enquanto não houver prova em contrário. Nesse sentido:

"A aprovação das contas pela assembleia geral corresponde, pois, a uma declaração de regularidade genérica, ou seja, o administrador exerceu o seu mandato e as respectivas contas foram aceitas pela assembleia. Configura-se em seu favor uma presunção de exoneração de responsabilidade, mas não uma garantia de impunidade. Trata-se de uma presunção juris tantum, destinada a prevalecer enquanto não se fizer uma prova em contrário, acenando o próprio texto legal para os vícios que possam comprometer a relatividade dessa presunção." ${ }^{47}$

Borba entende que qualquer ilegalidade é suficiente para desconstituir o quitus, sendo desnecessária a ação de desconstituição prevista no art. 286 da LSA:

"Para a ação de responsabilidade civil não se impõe, como condição prévia, a desconstituição da deliberação que aprovou as contas desses administradores. $O$ efeito dessa deliberação é uma presunção juris tantum. A presunção, no seu efeito genérico, poderá subsistir, a despeito das ações de responsabilidade civil, nas quais se produzirão as provas que terão o efeito de afastar a presunção relativamente aos casos concretos e às hipóteses que forem levados à apreciação dos tribunais. A presunção é genérica e abstrata, e assim permanecerá. A responsabilização civil será específica e concreta, e resultará dos fatos apurados." 48

Discordamos respeitosamente dessas duas posições, e alinhamo-nos com a parcela (majoritária) da doutrina que entende pela irrevogabilidade e irretratabilidade da aprovação de contas sem reservas, e consequentemente pela obrigatoriedade da desconstituição judicial do quitus.

A LSA é clara ao estabelecer que, caso as contas tenham sido aprovadas sem reservas, para que se possa ressuscitar a via da ação que visa responsabilizar algum administrador por ato ou fato ocorrido no período abarcado pelo quitus (ação do art. 159), é necessário primeiramente ingressar

\footnotetext{
${ }^{47}$ BORBA, José Edwaldo Tavares. In: FILHO, Alberto Venancio; LOBO, Carlos Augusto da Silveira; ROSMAN, Luiz Alberto Colonna (org.). Lei das S.A. em seus 40 anos, $1^{\mathrm{a}}$ ed. Rio de Janeiro: Forense, 2017 , p. 525-526.

${ }^{48}$ Ibid. p. 530-531.
} 
com uma ação para anular a assembleia geral como um todo, ou a deliberação específica por meio da qual se concedeu o quitus, pela ocorrência dos vícios de erro, dolo, fraude ou simulação (ação do art. 286).

Egberto Lacerda Teixeira e José Alexandre Tavares Guerreiro resumem esse entendimento ao afirmar que "enquanto não declarada judicialmente sua nulidade, valem as demonstrações financeiras como ato jurídico perfeito, com todos os efeitos daí decorrentes" $"$.

Essa é uma regra que permeia a lógica da legislação brasileira. Desde o Decreto-Lei $\mathrm{n}^{\circ}$ 2.627/1940, revogado pela LSA, a aprovação das contas impedia a propositura da ação de responsabilidade ${ }^{50}$. O atual art. $134, \S 3^{\circ}$ tem redação idêntica à do dispositivo que instituía essa regra no antigo diploma, e o Código Civil também replicou a regra em relação às sociedades limitadas ${ }^{51}$.

Não é à toa que o art. $134, \S 3^{\circ}$ da LSA faz ressalva expressa ao art. 286 da lei, que, por sua vez, fala em accão judicial para anular a deliberação viciada. Apenas o juiz (e não a assembleia) tem poder jurisdicional para reconhecer o vício de vontade de um acionista e para anular a deliberação da assembleia afetada por esse vício. Esse entendimento é assente na doutrina e na jurisprudência. O STJ, por exemplo, reconhece a inviabilidade jurídica da revogação do quitus por ato de assembleia posterior:

"A regra do artigo 134, $\S 3^{\circ}$, da Lei $n^{\circ} 6.404$, de 1976, é especial em relação à do artigo 159 - circunstância expressamente salientada pela remissão que aquela faz ao artigo 286 - de modo que, em se tratando de aprovação de contas, não basta a prévia deliberação da assembléia geral para a propositura da ação de

\footnotetext{
${ }^{49}$ TEIXEIRA, Egberto Lacerda; GUERREIRO, José Alexandre Tavares. Das Sociedades Anônimas no Direito Brasileiro, vol. I. São Paulo: Bushatsky, 1979, p. 416-417.

${ }^{50}$ Tal regra estava exposta no art. 101 do referido diploma:

"Art. 101. A aprovação, sem reserva, do balanço e das contas, exonera de responsabilidade os membros da diretoria e do conselho fiscal, salvo erro, dolo, fraude ou simulação (art. 156)."

51 “Art. 1.078. (...) § 3 o A aprovação, sem reserva, do balanço patrimonial e do de resultado econômico, salvo erro, dolo ou simulação, exonera de responsabilidade os membros da administração $e$, se houver, os do conselho fiscal."
} 
responsabilidade civil; é preciso que, antes ou concomitantemente, seja ajuizada a ação de anulação da deliberação da assembléia geral que aprovou as contas. $" 52 / 53$

A necessidade da desconstituição judicial do quitus decorre da impossibilidade de a própria assembleia geral reconsiderar a deliberação que aprovou suas próprias demonstrações financeiras e as contas de seus administradores.

Alfredo Lamy Filho, um dos formuladores da LSA, sintetiza perfeitamente esse entendimento:

"A exoneração de responsabilidade é um ato formalizado numa deliberação da Assembléia Geral Ordinária, praticado após o exame das contas, das demonstrações financeiras, do parecer de auditores independentes e do Conselho Fiscal (se houver) - que cria direitos para terceiros ou os exonera de responsabilidades e que não pode ser desconstituído por simples ato posterior ou deliberação da própria sociedade: A ação anulatória teria que ser proposta contra a assembléia que aprovou as contas." 54

Alfredo Sérgio Lazzareschi Neto reforça: "uma vez aprovadas, sem reservas, as contas e as demonstrações financeiras, assembleia posterior não pode "revogar" a deliberação anterior e decidir pela propositura de ação de responsabilidade contra os administradores" ${ }^{55}$.

\footnotetext{
${ }_{52}^{5 T J}$, Recurso Especial no 257.573 , Voto-Vista do Rel. para o acórdão Min. Ari Pargendler.

${ }^{53}$ Foi no mesmo sentido que o STJ julgou, em 29.06.2012, o REsp no $1.313 .725-\mathrm{SP}, 3^{\mathrm{a}}$ turma, rel. Ricardo Villas Boas Cuevas, em que a Sadia S.A. buscava reparação por prejuízos causados pelo exdiretor financeiro em decorrência de investimentos em derivativos cambiais, com violação à política de investimentos da sociedade. Segundo o voto do ministro relator, a previsão do art. $134, \S 3^{\circ}$ é especial em relação à do art. 159. Assim, quando as contas já tiverem sido aprovadas, é necessário ajuizar ação de anulação da assembleia que aprovou as contas antes ou concomitantemente à propositura da ação de responsabilidade. O relator afirmou que "somente após o trânsito em julgado da sentença que acolher a anulatória, pela ocorrência dos citados vícios, é possível ajuizar a ação de responsabilidade pertinente." Os seguintes julgados apresentaram decisões com a mesma orientação: AgRg no Ag n ${ }^{\circ} 640.050-R S, 4^{\mathrm{a}}$ turma, rel. Luis Felipe Salomão, julgado em 19.05.2009, e AgRg no Ag no 950.104-DF, $3^{a}$ turma, rel. Massami Uyeda, julgado em 19.03.2009.

${ }^{54}$ LAMY, Alfredo Filho, Temas de S.A., Rio de Janeiro: Renovar, 2007, p. 338-339.

${ }^{55}$ LAZZARESCHI NETO, Alfredo Sérgio. Efeitos da Aprovação das Contas e das Demonstrações Financeiras das Companhias. In: In: KUYVEN, Luiz Fernando Martins. Temas essenciais de direito empresarial: estudos em homenagem a Modesto Carvalhosa. São Paulo: Saraiva, 2012, p. 428.
} 
Sabe-se que a assembleia tem, em geral, ampla prerrogativa para ver e rever os mais diversos aspectos da vida da sociedade. É o órgão que tem por excelência, a função de decidir os negócios relativos ao objeto da companhia e consolidar a vontade social por meio do princípio majoritário.

A propósito ${ }^{56}$, Nelson Eizirik observa: "a assembleia geral pode sempre rever, ratificar ou retificar deliberações anteriores, resguardados os direitos de terceiros, pois é competente para decidir todos os negócios relativos ao objeto da companhia e tomar as resoluções que julgar convenientes à sua defesa e desenvolvimento." 57

Especificamente sobre as demonstrações financeiras, Fabio Konder Comparato proclama que, "investida de competência privativa para a aprovação de balanços, tem igualmente a assembleia geral de acionistas o poder exclusivo de retificar os já aprovados. Aliás, desde que reconheça a existência de vícios capazes de invalidar a aprovação já dada, a assembleia não somente pode, mas deve fazê-lo, como medida preliminar à ação de responsabilidade civil contra os administradores que já se encontraram na origem do vício" ${ }^{\prime 5}$.

No entanto, a prerrogativa de revisitar suas próprias deliberações encontra limites quanto se trata da revisão de atos que atingiram a esfera jurídica de terceiros - no caso, os administradores.

É difícil pensar em uma decisão assemblear que incida mais claramente na esfera de terceiros do que a aprovação das contas dos administradores, com sua consequente exoneração de responsabilidade. Os administradores são os destinatários fundamentais da aprovação das contas e o resultado dessa

\footnotetext{
${ }^{56}$ Comparato explica que, para atender ao princípio da veracidade dos balanços, a assembleia pode retificar os balanços, visando expurga-los de vícios, ou para exprimir com maior clareza a situação patrimonial da sociedade. COMPARATO, Fábio Konder. Natureza Jurídica do Balanço. In: Ensaios e Pareceres de Direito Empresarial. São Paulo: Forense, 1978, p. 31.

${ }^{57}$ EIZIRIK, Nelson. A Lei das S/A Comentada. Vol. II, $2^{\mathrm{a}}$ ed. São Paulo: Quartier Latin, 2015, p. 301.

${ }^{58}$ COMPARATO, Fabio Konder. Op. Cit., p. 31.
} 
deliberação produz efeito profundo sobre a sua esfera pessoal, na forma de exoneração plena.

Por isso, à assembleia geral é vedado revogar o ato que aprovou as contas, pois este ato - um reconhecimento negativo de dívida - cria um direito subjetivo para os administradores.

Nesse sentido, especificamente em relação ao quitus, Bulhões Pedreira e Luiz Alberto Colonna Rosman afirmam que "a assembléia não pode, ela própria, revogar o ato de aprovação das contas que criou direito para os administradores." 59

Trata-se, antes de tudo, de uma questão de segurança jurídica: apesar de ser um ato jurídico unilateral, a deliberação que outorga o quitus é irrevogável e irretratável pela própria companhia pois atinge diretamente terceiros.

Carlos Fulgêncio da Cunha Peixoto afirma que o princípio expresso na lei brasileira é o "de que toda pessoa, obrigada à prestação de contas, e que as vê aprovadas, tem direito a quitação." 60

Os acionistas não podem se reunir e simplesmente escolher revogar atos aprovados por outros acionistas. Se assim não fosse, os destinos dos administradores estariam eternamente à mercê das vontades de maiorias que se formam e se desfazem com o tempo.

Tullio Ascarelli esclarece: "a assembléia não pode, porém, como é natural, dispor de direito de terceiros, sem o consentimento deles."61

No mesmo sentido, ao tratar do instituto da revogação em termos gerais, Pontes de Miranda observa que "os nossos atos, se entram na esfera jurídica

\footnotetext{
${ }^{59}$ PEDREIRA, José Luiz Bulhões; ROSMAN, Luiz Alberto Colonna, Aprovação das Demonstrações Financeiras, Tomada de Contas dos Administradores e seus Efeitos. Necessidade de Prévia Anulação da Deliberação que Aprovou as Contas dos Administradores para a Propositura de Ação de Responsabilidade. In: CASTRO, Rodrigo R. Monteiro de; ARAGÃO, Leandro Santos de. Sociedade Anônima - 30 Anos da Lei 6.404/76. São Paulo: Quartier Latin, 2007, p. 56.

${ }^{60}$ PEIXOTO, Carlos Fulgêncio da Cunha. Sociedade por Ações. São Paulo: Saraiva, 1973, p. 113.

${ }^{61}$ ASCARELLI, Tullio. Problemas das Sociedades Anônimas e Direito Comparado. Campinas: Bookseller, 2001, p. 507.
} 
$\underline{\text { de outrem, }}$ hão de acompanhar-nos: revogar seria ir contra si-mesmo." ${ }^{.62}$ (sem grifos no original)

A ideia de que um grupo de acionistas reunidos em assembleia poderia simplesmente declarar que os acionistas reunidos em outra assembleia tinham suas vontades viciadas, e que, portanto, aquela deliberação não vale mais, simplesmente não é sustentável.

Caso essa revisão fosse possível, conforme a composição da assembleia geral e da administração variasse, se inauguraria um instrumento de vingança entre diferentes grupos de administradores, e entre acionistas e administradores que houvessem caído em desfavor.

Discordamos especialmente da posição de Carvalhosa no sentindo de que a revogação do quitus nem precisaria ser deliberada em assembleia, pois decorreria automaticamente da propositura da ação de responsabilidade. Caso a exoneração decorrente da aprovação de contas pudesse ser descartada mediante mera formalização, em assembleia posterior, da intenção de mover ação contra um administrador, o instituto do quitus seria totalmente esvaziado de sentido.

${ }^{62}$ PONTES DE MIRANDA. Tratado de Direito Privado. São Paulo: Revista dos Tribunais, 2013, T. V, p. 68. 


\section{IV - AS AÇÕES DOS ARTIGOS 286 E 159}

\subsection{A ação para desconstituição do quitus (art. 286)}

Como foi visto, partilhamos do entendimento de que que não basta a prévia deliberação da assembleia geral para o ingresso de ação de responsabilidade civil contra administradores, sendo sempre necessário anular a deliberação ou a assembleia que aprovou as contas, por meio de ação própria.

Trata-se da ação prevista no art. 286 da LSA, cabível contra deliberações tomadas em assembleia irregularmente convocada ou instalada, violadoras da lei ou do estatuto, ou eivadas de erro, dolo, fraude ou simulação.

A ação judicial para desconstituir a aprovação das contas não exige prévia aprovação da assembleia geral, diferentemente do ingresso da ação de responsabilidade contra o administrador, que fica sujeita à prévia aprovação pelos acionistas.

No entanto, a doutrina ${ }^{63}$ reconhece a possibilidade das ações de desconstituição do quitus e de responsabilidade serem propostas concomitantemente.

A legitimidade ativa para essa ação recai sobre os acionistas, uma vez

que ela gera efeitos sobre suas esferas patrimoniais. Como os defeitos que podem levar à anulação da deliberação que exonera a administração são vícios de vontade, apenas os acionistas, pessoal e individualmente, podem alega-los.

Assim, cabe ao acionista identificar o vício de vontade da formação do ato jurídico aparentemente perfeito e ingressar com a ação para anular tal vício. O acionista move a ação em seu interesse e por sua própria conta, e os administradores, por serem beneficiários do quitus, são litisconsortes ativos na ação anulatória. 
Por ser afetada diretamente pela desconstituição da deliberação ou da assembleia, a companhia fica sempre no polo passivo, respondendo pela deliberação por meio da qual sua própria vontade foi formada.

Por fim, destaca-se que a ação de anulação de que trata o art. 286 da LSA prescreve em 2 anos contados da deliberação que se pretende anular.

A respeito do prazo de prescrição para ajuizamento da ação, o Superior Tribunal de Justiça explica:

"Considera-se prescrita a ação de responsabilidade de administrador que teve suas contas aprovadas sem reservas pela assembleia geral, se esta não foi anulada dentro do biênio legal (...)". ${ }^{64}$

Ainda sobre o assunto, Alfredo Lamy Filho comenta:

"Se as contas foram fraudadas, e a deliberação que as aprovou foi produto de erro, dolo, fraude ou simulação, cabe à sociedade ir a juízo para reconhecimento do vício que a invalida. Para tanto, a Lei fixou-lhe o prazo de dois anos - contados da deliberação (e não da publicação da ata) porque a sociedade ou seus administradores não podem alegar desconhecimento do fato por ela própria praticado, pois a assembleia é a sociedade reunida para deliberar sobre assuntos sociais. ${ }^{65}$

O Decreto-Lei 2.627/40 estabelecia o mesmo prazo prescricional de três anos tanto para a ação de desconstituição da deliberação que outorgou a quitação quanto para a ação de responsabilidade civil contra o administrador. A LSA, atendendo às críticas de quem entendia ser um prazo muito longo para a anulação de uma deliberação de assembleia ${ }^{66}$, reduziu o prazo para dois anos, mantendo o prazo de três anos para a outra ação.

\footnotetext{
${ }^{63}$ EIZIRIK, Nelson. A Lei das S/A Comentada. Vol. II, $2^{\mathrm{a}}$ ed. São Paulo: Quartier Latin, 2015, p. 466. ${ }^{64}$ STJ, REsp no 256.596-SP. Min. rel. Antônio de Pádua Ribeiro, DJU 18.6.2001, p. 150.

${ }^{65}$ Parecer não publicado, anexo aos autos de ação de responsabilidade proposta pelo Banco do Brasil S.A. contra seu antigo presidente, Lafayete Coutinho Torres (caso examinado pelo STJ ao julgar o REsp n ${ }^{\circ}$ 256.596).

${ }^{66}$ Como Waldemar Ferreira, dentre outros.
} 
Desconstituída a deliberação que aprovou as contas dos administradores e as demonstrações financeiras sem ressalvas, fica desimpedido o caminho para a propositura de ação de responsabilidade contra o administrador.

\subsection{A ação de responsabilidade contra o administrador (art. 159)}

$\mathrm{O}$ art. 159 determina que a companhia poderá, mediante prévia deliberação dos acionistas reunidos em assembleia, instaurar ação de responsabilidade contra o administrador, visando reparação pelos danos que este tenha causado ao patrimônio social.

O momento usual para propositura dessa ação (chamada de ação social) é o momento de rejeição, ou aprovação com ressalvas, das contas dos administradores apreciadas em assembleia geral ordinária. O art. $159, \S 1^{\circ}$ da LSA determina que, mesmo quando não constar na ordem do dia, a deliberação poderá ser proposta e aprovada ${ }^{67}$.

Por outro lado, mesmo nas hipóteses em que tenham sido aprovadas as contas dos administradores, caso a deliberação por meio da qual se concedeu o quitus seja desconstituída, a assembleia geral poderá aprovar a propositura de ação de responsabilidade. Nesses casos, deverá ser convocada assembleia especialmente para esse fim.

A propositura da ação deverá observar o prazo prescricional de três anos previsto no art. 287, II da LSA ${ }^{68}$. Importante notar que a ação de anulação da

\footnotetext{
${ }^{67}$ Art. 159. Compete à companhia, mediante prévia deliberação da assembleia-geral, a ação de responsabilidade civil contra o administrador, pelos prejuízos causados ao seu patrimônio. $\S^{\circ} \mathrm{A}$ deliberação poderá ser tomada em assembleia-geral ordinária e, se prevista na ordem do dia, ou for consequência direta de assunto nela incluído, em assembleia-geral extraordinária.

${ }^{68}$ Art. 287. Prescreve:

(...)

II - em 3 (três) anos:

(..)

b) a ação contra os fundadores, acionistas, administradores, liquidantes, fiscais ou sociedade de comando, para deles haver reparação civil por atos culposos ou dolosos, no caso de violação da lei, do estatuto ou da convenção de grupo, contado o prazo:

(...)
} 
deliberação que concede o quitus prescreve em dois anos, enquanto a ação de responsabilidade prescreve em três anos. Como a ação de responsabilidade não pode prescindir da anulação da deliberação que aprovou as contas, decorridos dois anos, ambas estarão prescritas ${ }^{69}$.

Inclusive, e como será visto adiante, se for proposta a ação para anulação do quitus, e ela durar mais de 3 anos sem que tenha sido proposta a ação de responsabilidade, ficará prescrita a ação de responsabilidade. É uma questão que merece atenção.

Aprovada a propositura da ação de responsabilidade, o administrador será automaticamente impedido e deverá ser substituído na própria assembleia em que foi aprovada a ação. A lei prevê essa medida em seu art. $159, \S 2^{\circ}$ pois existe uma presunção de que, aprovada a propositura de ação de responsabilidade contra certo administrador, o vínculo de confiança entre os acionistas e ele é rompido.

Foi analisada a legitimidade para a ação desconstitutiva do quitus, prevista no art. 286. Quanto à legitimidade para a ação de responsabilidade contra o administrador, a partir da aprovação ou rejeição da sua propositura em assembleia, se inaugura uma ordem de legitimação processual específica.

Inicialmente, sendo aprovada a propositura da ação, a legitimação é da própria companhia, e nesse caso a ação é chamada de ação social ut universi. O prazo para ajuizamento da ação social ut universi é de três meses contados da deliberação da assembleia que aprovou a medida.

No entanto, caso a propositura da ação seja aprovada, mas o prazo de 3 meses para ingresso com a ação não seja observado pela companhia, surge para qualquer acionista a legitimidade para ingressar em juízo na qualidade de

2 - para os acionistas, administradores, fiscais e sociedades de comando, da data da publicação da ata que aprovar o balanço referente ao exercício em que a violação tenha ocorrido.

${ }^{69}$ EIZIRIK, Nelson. A Lei das S/A Comentada. Vol. IV, $2^{\mathrm{a}}$ ed. São Paulo: Quartier Latin, 2015, p. 526257. 
substituto processual da companhia. A ação nesse caso passa a ser chamada de ação social ut singuli, e trata-se de situação de legitimação extraordinária derivada, na medida em que decorre da omissão do legitimado ordinário ${ }^{70}$. Essa permissão visa coibir a lentidão da administração em ingressar com ação contra um de seus membros.

Por outro lado, se a assembleia geral deliberar não promover a ação, acionistas que representem pelo menos cinco por centro do capital social poderão fazê-lo ${ }^{71}$. Nesse caso, a ação continua sendo chamada de ação social $u t$ singuli, já que o acionista age em nome próprio, mas em benefício da companhia.

Trata-se de uma hipótese de legitimação extraordinária originária, pois decorre de uma escolha do acionista ou grupo de acionistas e não da omissão da companhia em relação a uma obrigação que deixou de cumprir.

É importante notar que, no caso da ação social ut singuli por legitimação extraordinária originária, o acionista será responsável pelos custos e eventuais prejuízos da ação, enquanto que a companhia será a titular da pretensão deduzida em juízo, e, portanto, a beneficiária de eventuais ganhos.

Ao criar essa possibilidade, o legislador pretendeu coibir a situação em que o controlador, responsável pela indicação do administrador para o cargo, consegue impedir que a assembleia aprove a propositura da ação para responsabilizá-lo, perpetrando um quadro de injustiças e de prejuízo ao patrimônio social.

Discute-se, no entanto, a efetividade dessa permissão, na medida em que existem mais fatores de desestímulo aos acionistas para ingressar com esse tipo de ação (altos custos e suporte exclusivo dos prejuízos) do que de estímulo (o acionista é apenas beneficiário indireto na hipótese de a ação vir a ser

\footnotetext{
${ }^{70}$ Art. $159, \S 3^{\circ}$ LSA.

${ }^{71}$ Art. $159, \S 4^{\circ}$ LSA.
} 
considerada procedente). Por outro lado, ela também evita que acionistas promovam ações frívolas em detrimento dos administradores, que, lembre-se, são destituídos quando da propositura da ação de responsabilidade. 


\section{V - AS CONTRADIÇÕES DO SISTEMA BRASILEIRO}

Vimos que existe uma discussão em que parte da doutrina entende que existe a possibilidade de se desconstituir o quitus por via extrajudicial, ou seja, por uma deliberação posterior de assembleia. Há quem entenda ainda que nem se exige a deliberação posterior, estando o quitus tacitamente revogado pela aprovação da ação de responsabilidade prevista no art. 159 da LSA. Por outro lado, a doutrina majoritária é no sentido de que a desconstituição do quitus só pode ser feita judicialmente, por meio da ação prevista no art. 286 da LSA.

Fora a referida discussão, tratamos do procedimento de desconstituição do quitus e de propositura da ação de responsabilidade contra o administrador sem vislumbrar grandes complicações aparentes sobre o tema. À primeira vista, a estrutura da lei brasileira parece fazer sentido e estabelecer um mecanismo organizado para o processo de revogação do quitus e responsabilização do administrador.

No entanto, quando analisamos a questão de forma mais detida, e especialmente sob um enfoque procedimental, vemos que existem algumas complicações e contradições inerentes ao sistema estabelecido pela nossa lei.

Inicialmente, e de acordo com a corrente doutrinária majoritária (com a qual concordamos), vimos que são necessárias duas ações para viabilizar o procedimento de responsabilização do administrador em relação a um período abarcado pelo quitus. A primeira, nos termos do art. 286 da LSA, terá como objetivo a anulação da deliberação ou assembleia nos casos já examinados, e terá como consequência a desconstituição do quitus. A segunda, nos termos do art. 159, terá como objetivo e possível consequência a responsabilização do administrador por prejuízos causados ao patrimônio social.

Vimos que a doutrina e a jurisprudência não encontram problemas em afirmar que essas ações podem ser propostas concomitantemente. No entanto, 
pouco se discute sobre o problema que é a compatibilização, na prática, da legitimidade ativa para essas duas ações.

Foi visto acima que a companhia será sempre ré na ação que visa a desconstituição. As deliberações tomadas em assembleia viram ato próprio da companhia, que não realiza juízo de valor sobre suas deliberações nem se insurge contra o processo de formação da sua própria vontade.

A companhia jamais poderia ocupar o polo ativo na ação do art. 286 da LSA pois ela não pode substituir o acionista na interpretação de qual teria sido a sua vontade em assembleia. Ela não pode deduzir pleito anulatório em nome próprio, alegando que sua vontade estava viciada.

Por outro lado, vimos que a companhia é a legitimada ativa por excelência no caso da ação social, prevista no caput do art. 159 da LSA.

Assim, quando a atuação de um administrador causar prejuízo ao patrimônio da companhia, será no interesse da sociedade ingressar com ação de responsabilidade contra ele. Mas quando os acionistas reunidos em assembleia tiverem aprovado as contas daquele administrador, a viabilidade da ação de responsabilidade (que é de interesse da companhia) vai requerer a procedência de uma ação prévia que é de interesse contrário ao da companhia, pois pretende a desconstituição de um ato de vontade seu.

Ou seja, para poder buscar a recomposição de seu patrimônio prejudicado, a companhia precisa que uma terceira pessoa desconstitua uma deliberação que consubstancie um ato de vontade seu. A companhia precisa perder a primeira ação para ganhar o direito de ingressar com a outra, necessária para responsabilizar o administrador e recuperar o prejuízo que o patrimônio social sofreu.

Essa situação pode parecer menos estranha nas hipóteses de substituição processual e legitimação extraordinária originária previstas nos $\S \S 3^{\circ}$ e $4^{\circ}$ do art. 159 da LSA, pois será o acionista que figurará no polo ativo tanto da ação 
de desconstituição do ato de vontade da companhia, quanto da ação que visa responsabilizar o administrador.

De qualquer forma, há de se lembrar que o beneficiário da eventual procedência da ação de responsabilidade (seja ela proposta nos termos do caput do art. 159 ou de um de seus $\S \S$ mencionados acima) será sempre a companhia.

E qual poderia ser a solução para esse problema de legitimação processual? Pode-se sustentar que a ação de desconstituição da deliberação que outorgou o quitus simplesmente não pode ser proposta de forma concomitante à ação de responsabilidade.

Um possível argumento para sustentar essa teoria seria de que a vontade da companhia de responsabilizar o administrador apenas surge no momento em que há procedência da ação do art. 286, ou seja, quando se prova que a deliberação/assembleia por meio da qual se outorgou o quitus foi viciada, sendo ela devidamente desconstituída e o quitus revogado.

Acontece que essa aparente solução encontra um entrave substancial nos prazos prescricionais para propositura das ações do art. 286 e 159.

Vimos que a ação do art. 286 prescreve em 2 anos contados da deliberação que se visa anular. A ação de responsabilidade do administrador, por sua vez, prescreve em 3 anos contados da data da publicação da ata que aprovar o balanço referente ao exercício em que a violação tenha ocorrido (art. 287, II, alínea b, item “A”).

De acordo com essa solução, o interesse processual da companhia para ação do art. 159 (segunda ação, na qual a companhia normalmente figura como autora) surgiria apenas se e quando a ação do art. 286 (primeira ação, na qual a companhia figura como ré) fosse julgada procedente.

Mas nesse caso, toda vez que a ação de desconstituição se estender por mais de 3 anos - o que não é nada improvável considerando a média de duração das ações no judiciário brasileiro - a ação de responsabilidade estaria prescrita. 
Insistindo no assunto, poderia ser sustentado que uma solução para a controvérsia toda seria a propositura separada, mas concomitante, das duas ações (com distribuição por dependência, por exemplo), ficando a validade da segunda ação pendente da procedência da primeira, como uma espécie de condição da ação.

O art. 313, V, alínea "a" do Novo Código de Processo Civil determina: “Art. 313. Suspende-se o processo: (...) V-quando a sentença de mérito: a) depender do julgamento de outra causa ou da declaração de existência ou de inexistência de relação jurídica que constitua o objeto principal de outro processo pendente". Este poderia ser o fundamento utilizado para obter a suspensão da segunda ação enquanto fosse julgada a primeira. $\mathrm{O}$ efeito seria o mesmo do previsto acima, e a propositura conjunta evitaria o perigo da prescrição da segunda ação.

Essa saída resolveria o problema do prazo prescricional, mas as complicações resultantes da legitimidade processual nas duas ações, conforme visto acima, permaneceriam um problema.

Percebe-se, por todo o exposto neste capítulo, que a sistemática da lei brasileira de responsabilização dos administradores na situação em que o quitus já tenha sido outorgado apresenta obstáculos de cunho prático e processual que não podem ser facilmente ultrapassados. 


\section{VI - REFLEXÕES PARA APRIMORAMENTO DO SISTEMA BRASILEIRO}

O tema do quitus e da responsabilidade dos administradores é complexo e se desdobra em várias questões relacionadas. Não é à toa que o assunto é alvo de questionamentos e debates em diversos ordenamentos. Na presente seção, faremos reflexões sobre situações e saídas que poderiam solucionar alguns dos conflitos inerentes ao sistema da lei brasileira.

Uma forma de buscarmos soluções para os nossos obstáculos é olhando para o lado e analisando como os outros solucionam problemas similares. Na elaboração do presente trabalho, estudou-se como diferentes ordenamentos jurídicos tratam o assunto do quitus e da responsabilização dos administradores de sociedades anônimas, e se algum deles apresenta soluções que poderiam ser com alguma facilidade importadas para o nosso sistema.

Em conclusão a esse estudo, verificou-se que o ordenamento jurídico português dá ao assunto um tratamento interessante, que, se aplicado no Brasil, poderia solucionar grande parte dos problemas estudados na seção anterior.

E o que diz o ordenamento lusitano sobre essa questão? O entendimento em Portugal é de que, quando os acionistas se reúnem em assembleia e aprovam as contas e demonstrações financeiras, outorgando o quitus aos administradores, essa quitação abarca apenas o que era conhecido por tais acionistas.

Assim, tudo aquilo que não for levado ao conhecimento dos acionistas seja por um erro de atuação dos administradores, que não incluíram certo fato ou ato no relatório da administração ou nas demonstrações financeiras, seja por intuito fraudulento dos administradores, que praticaram atos ilícitos e propositalmente os ocultaram dos acionistas - simplesmente não estará abarcado pelo quitus. 
O art. 74, item 3 do Código das Sociedades Comerciais de Portugal (Decreto-Lei $n^{\circ}$ 262/86) determina:

"A deliberação pela qual a assembleia geral aprove as contas ou a gestão dos gerentes ou administradores não implica renúncia aos direitos de indemnização da sociedade contra estes, salvo se os factos constitutivos de responsabilidade houverem sido expressamente levados ao conhecimento dos sócios antes da aprovação e esta tiver obedecido aos requisitos de voto exigidos pelo número anterior."

Vejamos a explicação de Pinto Furtado sobre o assunto:

"Esta deliberação [da assembleia geral], relativamente à proposta de lucros $e$ perdas, constitui uma verdadeira manifestação de vontade social. No tocante às contas, porém, apresenta mero valor assertório, dispondo a tal respeito a lei para as sociedades anônimas que, ao aprovar a gestão dos administradores, ela não implica renúncia aos direitos de indenização da sociedade contra estes, salvo se os fatos constitutivos da responsabilidade houverem sido expressamente levados ao conhecimento da mesma assembleia antes da aprovação e esta tiver obedecido aos requisitos de voto exigidos para a renúncia ao direito de indenização."72

Nesse entendimento, a quitação da forma como explicada no presente trabalho, com todas as consequências daí advindas (como a impossibilidade de ingresso de ação de responsabilidade contra os administradores) só vale para o que efetivamente consta nas demonstrações financeiras e nas contas, ou seja, o que tive sido conhecido pelos acionistas. Isso porque eles não poderiam dar quitação sobre atos ou fatos que não eram de seu conhecimento.

Eventuais ilícitos praticados também não vêm ao conhecimento da assembleia, e, por não serem considerados pelos acionistas para outorga da quitação aos administradores, também não são abarcados pelo quitus.

Assim, a quitação simplesmente não seria considerada como tendo sido outorgada, podendo se ingressar diretamente com ação de responsabilidade contra os administradores em relação a tudo que não estivesse nas demonstrações financeiras e nas contas. Não seria necessário ingressar com

\footnotetext{
${ }^{72}$ FURTADO, Pinto. Curso de direito das sociedades. Coimbra: Almedina, 1986, p. 281.
} 
ação de desconstituição do quitus, prevista no art. 286 da LSA, pois não haveria necessidade de desconstituir o que não havia sido outorgado em primeiro lugar.

Consequentemente, se esse tratamento fosse importado para o direito brasileiro, as hipóteses em que ainda subsistiriam os problemas vistos na seção anterior - pois ainda seria necessário ingressar tanto com a ação de desconstituição do quitus prevista no art. 286 da LSA, quanto com a ação de responsabilidade prevista no art. 159 da LSA - seriam reduzidas a quase zero.

Essas hipóteses se configurariam apenas quando o motivo para responsabilizar o administrador estivesse expresso nas contas e nas demonstrações financeiras mas não tivesse relação com alguma fraude ou ilegalidade.

Concebemos apenas uma situação que se enquadraria nesses parâmetros. Seria o caso de atuação com negligência por parte do administrador. Nesse caso, o administrador teria consignado nas contas e demonstrações financeiras um retrato fidedigno de sua atuação, e, portanto, os acionistas teriam plena consciência daquele ato ou fato ao aprovarem o balanço e as contas. No entanto, percebendo posteriormente que aquele ato ou fato teria trazido prejuízos ao patrimônio da sociedade, mas não por fraude ou ilegalidade, e sim por negligência do administrador, os acionistas teriam que anular a quitação outorgada, para então proceder com a ação de responsabilidade.

De qualquer forma, parece uma situação de difícil concretização, motivo pelo qual a aplicação das regras portuguesas ao nosso ordenamento para tratamento da questão do quitus poderia ser uma boa solução aos diversos problemas que decorrem da necessidade de ingresso das ações previstas nos arts. 286 e 159 da LSA para desconstituição do quitus e responsabilização do administrador. 
Além do mais, vimos que, no nosso ordenamento, quando a assembleia aprova as contas dos administradores, ela acaba não tendo conhecimento sobre os detalhes dos contratos ou operações realizadas pelos administradores. As demonstrações financeiras apresentam apenas sínteses contábeis e o relatório da administração deixa de expressar uma quantidade enorme de informações importantes.

Assim, a aplicação no direito brasileiro de uma norma similar à do ordenamento português seria um bom estímulo aos administradores para que, na elaboração dos documentos a serem submetidos aos acionistas para deliberação em assembleia, incluíssem o máximo de informações possíveis nos documentos, que seriam muito mais completos do que são atualmente.

Aqui vale fazer um parêntese para notar que o tratamento da lei portuguesa à matéria do quitus em muito se assembleia ao entendimento expresso por José Edwaldo Tavares Borba ao estudar o assunto em nosso ordenamento, segundo demonstrado na seção 4.2 acima.

Conforme explicado, discordamos de que a matéria, no nosso direito vigente, possa ser interpretada da forma como faz Borba, simplesmente porque não é o que a nossa lei determina. Com a redação atual da lei de sociedades anônimas brasileira, não se poderia interpretar que a desconstituição do quitus prescinda da ação judicial do art. 286 da LSA, independentemente do motivo pelo qual se busque a desconstituição.

No entanto, caso a nossa lei viesse a ser alterada para refletir a solução da lei portuguesa, aí sim a interpretação e solução de Borba fariam sentido, e estariam resolvidos diversos dos problemas mencionados na seção anterior. Mas, antes disso, não se pode simplesmente ignorar o disposto nos arts. 134, $\S 3^{\circ}$ e 286 da LSA. Afinal de contas, a lei foi escrita para ser cumprida, gostemos ou não. 


\section{CONCLUSÃO}

O propósito do presente trabalho era demonstrar os contornos e complicações de um tópico central ao estudo das sociedades anônimas no direito brasileiro: a responsabilidades dos seus administradores.

Vimos que essas pessoas ocupam um papel central no dia a dia e no funcionamento das sociedades, na medida em que são responsáveis pela gestão do capital de terceiros, e por determinar e executar a vontade da sociedade dentro dos parâmetros do seu objeto social.

Considerando as características de seu trabalho, os administradores precisam de certa flexibilidade para atuarem da melhor forma possível, mas essa flexibilidade também demanda a possibilidade de fiscalização pelos acionistas da atuação dos administradores. É por isso que a lei exige que os administradores reportem aos acionistas após o término do exercício social, submetendo as demonstrações financeiras e suas contas à aprovação em assembleia.

Dessa aprovação é que surge o quitus, a exoneração de responsabilidade pelos atos abarcados pelo período da quitação, com consequente entrave à propositura pela companhia da ação de responsabilidade prevista no art. 159 da LSA.

Vimos que, nos casos em que o quitus tenha sido outorgado mas se busca responsabilizar o administrador, o nosso direito exige a prévia desconstituição judicial dessa quitação. A doutrina majoritária entende que, apenas com a procedência da ação prevista no art. 286 da LSA, fica desimpedido o caminho para propositura da ação de responsabilidade do art. 159.

No entanto, essa sistemática cria certas complicações, notadamente quanto à legitimidade ativa e passiva das duas ações, e em relação aos 
diferentes prazos prescricionais. Pode-se buscar diferentes saídas para esses problemas, mas o fato é que a nossa lei contém alguns entraves específicos que são aparentemente insuperáveis.

Para não ficarmos apenas nos problemas, buscamos uma solução para essas dificuldades em um ordenamento próximo. $\mathrm{O}$ direito português permite uma saída interessante ao não reconhecer a extensão do quitus a toda informação que não constar dos documentos elaborados pela administração e submetidos à aprovação pela assembleia geral, bem como quaisquer fraudes ou ilegalidades, por se tratarem de assuntos não abarcados pela exoneração pretendida pelos acionistas.

Não tendo sido outorgada a quitação em relação a tais matérias, torna-se desnecessária a propositura da ação de desconstituição prevista no art. 286 da LSA, por não haver o que se desconstituir. O caminho estará, de pronto, desimpedido para a propositura da ação de responsabilidade prevista no art. 159 da LSA, solucionando, assim, os problemas de legitimidade ativa e prescrição que surgem em decorrência da propositura concomitante ou dependente dessas duas ações.

Trata-se de uma solução positiva, e inclusive já vislumbrada pela doutrina no âmbito do direito brasileiro. Mas não se pode confundir uma reflexão para possibilidade de mudança com uma interpretação do texto de lei vigente. Nos termos de nossa legislação atual, e conforme reconhecido pela doutrina majoritária, quando os acionistas reunidos em assembleia aprovarem as contas dos administradores e as demonstrações financeiras sem ressalvas, os administradores estarão exonerados de responsabilidade.

Enquanto o texto de nossa lei permanecer como é, não se pode desviar dessa interpretação, sob pena de criar-se uma enorme insegurança jurídica para as pessoas que exerçam os cargos de administradores, que precisam de liberdade de atuação e espaço para tomada de riscos. Conforme mencionado acima, toda pessoa obrigada à prestação de contas e que as vê aprovadas tem 
direito à quitação. E simplesmente não podemos deixar os destinos desses profissionais eternamente à mercê de vontades e interesses das maiorias que se fazem e desfazem com o tempo. 


\section{BIBLIOGRAFIA}

1. ADAMEK, Marcelo Vieira Von. Responsabilidade Civil dos Administradores de S/A (e as ações correlatas). São Paulo: Saraiva, 2009, p. 48.

2. ASCARELl, Tullio. Problemas das Sociedades Anônimas e Direito Comparado. Campinas: Bookseller, 2001, p. 507

3. BORBA, José Edwaldo Tavares. In: FILHO, Alberto Venancio; LOBO, Carlos Augusto da Silveira; ROSMAN, Luiz Alberto Colonna (org.). Lei das S.A. em seus 40 anos, $1^{a}$ ed. Rio de Janeiro: Forense, 2017, p. 522-523.

4. CAMPOS, Luiz Antonio de Sampaio. Conselho de administração e diretoria. In: LAMY FILHO, Alfredo; PEDREIRA, José Luiz Bulhões (coord.). Direito das Companhias. Rio de Janeiro: Forense, 2009, p. 790.

5. CARVAlhosA, Modesto. Comentários à Lei de Sociedades Anônimas. Vol. IV, $5^{\text {a }}$ ed. São Paulo: Saraiva, 2014, p. 554

6. COMPARATO, Fábio Konder. Natureza Jurídica do Balanço. In: Ensaios e Pareceres de Direito Empresarial. São Paulo: Forense, 1978, p. 31

7. EIZIRIK, Nelson. A Lei das S/A Comentada. Vol. II, $2^{\mathrm{a}}$ ed. São Paulo: Quartier Latin, 2015, p. 301.

8. EIZIRIK, Nelson. A Lei das S/A Comentada. Vol. III, $2^{\mathrm{a}}$ ed. São Paulo: Quartier Latin, 2015, p. 20. 
9. ENDEMANN, WILHEIM. Apud.: LAMY FILHO, Alfredo; PEDREIRA, José Luiz Bulhões (coord.). Direito das Companhias. Rio de Janeiro: Forense, 2009, p. 636.

10. FERREIRA, Waldemar. Tratado das Sociedades Mercantis. Rio de Janeiro: Editora Nacional, 1958, p. 1817.

11. FURTADO, Pinto. Curso de direito das sociedades. Coimbra: Almedina, 1986, p. 281.

12. GUIMARAES, Ruy Carneiro. Sociedades por ações. Rio de Janeiro: Forense, 1960, p. 274

13. LAMY, Alfredo Filho, Temas de S.A., Rio de Janeiro: Renovar, 2007, p. 338-339

14. LAZZARESCHI NETO, Alfredo Sérgio. Efeitos da Aprovação das Contas e das Demonstrações Financeiras das Companhias. In: KUYVEN, Luiz Fernando Martins. Temas essenciais de direito empresarial: estudos em homenagem a Modesto Carvalhosa. São Paulo: Saraiva, 2012, p. 423-424.

15. MARTINS, Fran. Comentários à Lei das Sociedades Anônimas, t. 1, vol. 2. Rio de Janeiro: Forense, 2010, p. 234.

16. NOVAES FRANÇA, Erasmo Valladão Azevedo. Invalidade das deliberações de assembleia das S.A. São Paulo: Malheiros, 1999, p. 88

17. PEDREIRA, José Luiz Bulhões; ROSMAN, Luiz Alberto Colonna, Aprovação das Demonstrações Financeiras, Tomada de Contas dos Administradores e seus Efeitos. Necessidade de Prévia Anulação da Deliberação que Aprovou as Contas dos Administradores para a Propositura 
de Ação de Responsabilidade. In: CASTRO, Rodrigo R. Monteiro de; ARAGÃO, Leandro Santos de. Sociedade Anônima - 30 Anos da Lei 6.404/76. São Paulo: Quartier Latin, 2007, p. 43.

18. PEIXOTO, Carlos Fulgêncio da Cunha. Sociedade por Ações. São Paulo: Saraiva, 1973, p. 113

19. PONTES DE MIRANDA. Tratado de Direito Privado. T. L, $3^{\text {a }}$ ed. São Paulo: Revista dos Tribunais, 1984, p. 385.

20. RAMALHETE, Vanessa Santos Neves. Responsabilidade dos Administradores de Sociedades Anônimas. Rio de Janeiro: Lumen Juris, 2009, p. 53.

21. TEIXEIRA, Egberto Lacerda; GUERREIRO, José Alexandre Tavares. Das Sociedades Anônimas no Direito Brasileiro, vol. I. São Paulo: Bushatsky, 1979, p. 416-417.

22. TEPEDINO, Ricardo. Assembleia Geral. In: LAMY FILHO, Alfredo; PEDREIRA, José Luiz Bulhões (coord.). Direito das Companhias. Rio de Janeiro: Forense, 2009, v. I, p. 634.

23. VALVERDE, Trajano de Miranda. Sociedades por Ações, vol. II, $2^{\mathrm{a}}$ ed. Rio de Janeiro: Forense, 1953, p. 138.

24. STJ, AgRg no Ag $\mathrm{n}^{\circ}$ 950104-DF, Rel. Min. Massami Yueda, 30.03.2009.

25. STJ, REsp n ${ }^{\circ}$ 257.573, Rel. Min. Ari Pargendler, 08.05.2001.

26. STJ, REsp no 1.313.725-SP, Rel. Min. Ricardo Villas Boas Cuevas, 29.06.2012. 
27. STJ, AgRg no $\mathrm{Ag} \mathrm{n}^{\circ}$ 640.050-RS, Rel. Min. Luis Felipe Salomão, 19.05.2009.

28. STJ, AgRg no Ag $\mathrm{n}^{\circ}$ 950.104-DF, Rel. Min. Massami Uyeda, 19.03.2009.

29. STJ, REsp n ${ }^{\circ}$ 256.596, Rel. Min. Nancy Andrighi, 08.05.2001. 
Pontifícia Universidade Católica

NORMAS PARA ELABORAÇÃO E APRESENTAÇÃO DA MONOGRAFIA

\section{ANEXO II}

\section{A Monografia deve ser entregue atć o dia 21 de novembro de 2018}

A presente Monografia, apresentada pelo (a) aluno (a)

MACIEL SEATA

poderá ser submetida à exposição e defesa perante a Banca Examinadora designada pelo Departamento de Direito da PUC-Rio.

Rio de Janeiro, 19 de Movreulu de 2018.

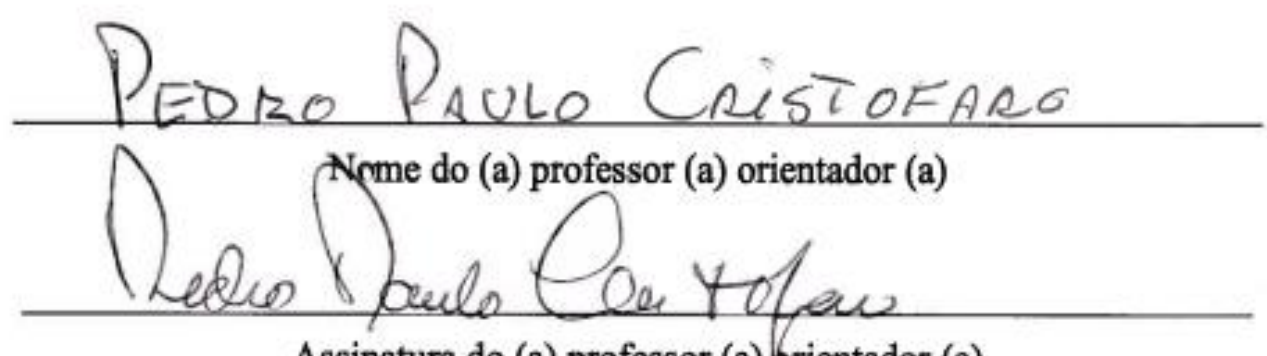

Assinatura do (a) professor (a) prientador (a)

O (A) autor (a) deste trabalho declara para todos os fins de Direito ser este um trabalho inédito e autoriza o Departamento de Direito da PUC-Rio a divulgá-lo, no todo ou em parte, resguardados os direitos autorais conforme legislação vigente.

Rio de Janeiro, 14 de nove rmblo 2018.

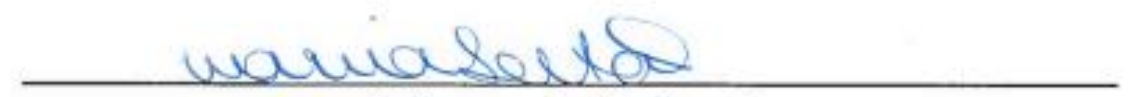

Assinatura do (a) aluno (a) 